\title{
The Impact of a Modified Cooperative Learning Technique on the Grade Frequencies Observed in a Preparatory Chemistry Course
}

\author{
Bridget J. Hayes Russell \\ West Virginia University
}

Follow this and additional works at: https://researchrepository.wvu.edu/etd

\section{Recommended Citation}

Hayes Russell, Bridget J., "The Impact of a Modified Cooperative Learning Technique on the Grade Frequencies Observed in a Preparatory Chemistry Course" (2011). Graduate Theses, Dissertations, and Problem Reports. 3099.

https://researchrepository.wvu.edu/etd/3099

This Dissertation is protected by copyright and/or related rights. It has been brought to you by the The Research Repository @ WVU with permission from the rights-holder(s). You are free to use this Dissertation in any way that is permitted by the copyright and related rights legislation that applies to your use. For other uses you must obtain permission from the rights-holder(s) directly, unless additional rights are indicated by a Creative Commons license in the record and/ or on the work itself. This Dissertation has been accepted for inclusion in WVU Graduate Theses, Dissertations, and Problem Reports collection by an authorized administrator of The Research Repository @ WVU.

For more information, please contact researchrepository@mail.wvu.edu. 
The Impact of a Modified Cooperative Learning Technique on the Grade Frequencies Observed in a Preparatory Chemistry Course

Bridget J. Hayes Russell, M.A.

Dissertation submitted to the College of Human Resources and Education

at West Virginia University in partial fulfillment of the requirements

for the degree of

Doctor of Education

in

Educational Psychology

Daniel E. Hursh, Ph.D. (Chair)

Michelle Richards Babb, Ph.D.

Reagan Curtis, Ph.D.

Patricia A. Haught, Ed.D.

Emily Sweitzer, Ed.D.

Morgantown, West Virginia

2011

Keywords: Cooperative Learning, Preparatory Chemistry 


\begin{abstract}
ABSRACT
The Impact of a Modified Cooperative Learning Technique on the Grade Frequencies Observed in a Preparatory Chemistry Course
\end{abstract}

\title{
Bridget J. Hayes Russell
}

This dissertation explored the impact of a modified cooperative learning technique on the final grade frequencies observed in a large preparatory chemistry course designed for pre-science majors. Although the use of cooperative learning at all educational levels is well researched and validated in the literature, traditional lectures still dominate as the primary methodology of teaching. This study modified cooperative learning techniques by addressing commonly cited reasons for not using the methodology. Preparatory chemistry students were asked to meet in cooperative groups outside of class time to complete homework assignments. A chi-square goodness-of-fit revealed that the final grade frequency distributions observed were different than expected. Although the distribution was significantly different, the resource investment using this particular design challenged the practical significance of the findings. Further, responses from a survey revealed that the students did not use the suggested group functioning methods that empirically are known to lead to more practically significant results. 


\section{Dedication}

Family, career, and education are difficult to balance all at one time. As a result, my doctoral journey took longer than planned. I would like to dedicate this work to my mentor, Dr. James S. Hillgren, Ph.D. Jim encouraged me to recommit to my studies and to finish school at a very busy time in my personal life and career. More than encourage, he made it possible for me to take the time from work to accomplish this goal so that my husband and children wouldn't feel the impact or lose time with me. Jim was an accomplished man and a leader. He was able to bring out the best in everyone he touched. He was calm, nurturing, optimistic, and funny, yet still challenging. Our world was forever changed when we lost Jim to pancreatic cancer on October 30, 2011. However, the legacy of man like Jim cannot be measured in numbers or time... his impact is so much bigger than that. I am only one of many, many examples of how Jim changed the lives of those around him for the better.

Jim... thanks for the encouragement, time, and space to do this work. I could not have done this without your support.

Forever inspired, Bridget 


\section{Acknowledgements}

First and foremost, I acknowledge God for the abilities to complete this work and for providing such a wonderful support system.

Next, thank you to my husband, Jim and our three little ones: J.R., Markie, and Matthew. All that I do is and will forever be for you. Thank you for a wonderful family and life. I acknowledge and appreciate the sacrifices you've made to allow me to fulfill my dreams and goals.

Finally, I thank my parents, Barbara Oliverio and Mark Hayes. This body or work and degree are just as much for the two of you. I realize and appreciate the sacrifices you made so selflessly to provide me with such a wonderful life and opportunity. I love you both and am forever grateful to have you as parents. 


\section{Table of Contents}

$\begin{array}{lll}\text { Abstract } & \text { Page ii }\end{array}$

$\begin{array}{ll}\text { Dedication } & \text { Page iii }\end{array}$

Acknowledgements $\quad$ Page iv

$\begin{array}{ll}\text { Chapter 1: Introduction } & \text { Page } 1\end{array}$

$\begin{array}{ll}\text { Chapter 2: Literature Review } & \text { Page } 4\end{array}$

$\begin{array}{ll}\text { Chapter 3: Method } & \text { Page } 16\end{array}$

Chapter 4: Results $\quad$ Page 24

$\begin{array}{ll}\text { Chapter 5: Discussion } & \text { Page } 32\end{array}$

$\begin{array}{ll}\text { References } & \text { Page } 38\end{array}$

Appendices

Appendix A: Chemistry 110 Group Homework Evaluation Page 43

Appendix B: Chemistry 110 Course Syllabus $\quad$ Page 50

Appendix C: Chemistry 110 Group Homework Overview Page 57

Appendix D: Cooperative Learning Workbook Page 67

Figures

Figure 1: Six-year historical DFW percentages observed in preparatory chemistry.

Figure 2: A comparison of cooperative learning final grades to historical final grades 


\section{Table of Contents}

Tables

Table 1: Five Components of Cooperative Learning Groups Page 5

Table 2: Individual Contribution Rating Scale $\quad$ Page 22

Table 3: Final Grade Frequencies Observed During Study $\quad$ Page 26

Table 4: Chi-Square Test of Goodness-of-Fit $\quad$ Page 28

Table 5: Internal Reliability of the Group Homework Survey Page 32 


\section{Introduction}

Overall, students interact with one another in one of three ways: competitively, individually, or cooperatively, and the majority of students in the United States view school competitively (Johnson \& Johnson, 1988). Spelling bees, races, math competitions, and valedictorian aspirations are a few examples of the competitive activities common within the educational system in the United States. Individual efforts also are part of mainstream educational practices, as most classrooms use criterion-referenced grading scales that provide students with a grade based on individual effort (e.g., earning a 90\% is awarded an “A” letter grade).

Johnson and Johnson (1989) synthesized 100 years of research examining the impact of these three interaction patterns on academic achievement. Their meta-analysis found that the average person in a cooperative situation outperformed individuals in competitive or individual situations by two-thirds of a standard deviation. They also concluded that, in contrast to competitive or individualistic efforts, cooperative learning yielded greater retention, cooperation, willingness to take on difficult tasks and persist, higher-level reasoning, critical thinking, creative thinking, meta-cognitive thought, positive attitudes toward tasks, time on task, and generalization across settings and individuals. Cooperative learning has been researched thoroughly and is a proven instructional tool for improving student achievement, regardless of factors such as age, content, discipline, educational level, ethnicity, or sex.

Although cooperative learning is a respected educational practice well validated in the literature, the majority of university professors in the United States use traditional lectures as their primary teaching strategy (Ediger, 2001; Murray \& Murray, 1992). In fact, the Foundation Coalition (http://www.foundationcoalition.org/home/keycomponents/collaborative_learning.html), 
an engineering educational community funded by the National Science Foundation, contends that 89\% of science and math instructors use lectures as their preferred teaching strategy. So despite convincing literature, why are lectures still being used as the primary teaching methodology? Cooperative learning is a time-consuming methodology and, when used with large sections of students, can be difficult to manage for instructors during class time. Using class time for group work is typically a concern for instructors who need to cover large amounts of material in a short period (Felder \& Brent, 1996; Sheridan, Byrne, \& Quina, 1989).

In addition to the time needed to implement traditional cooperative learning methodologies, Cooper (1995) discussed two additional perceived deterrents. First, instructors relinquish a significant amount of control, and classrooms often become noisy. Second, many professors are uncertain of how to minimize the "hitch hiker" effect, which describes a situation in which a few exemplar students in the group complete the majority of the work while others do not contribute. Although these and other deterrents are discussed in the literature, no studies evaluating modifications that addressed the deterrents were found. The purpose of this study was to examine the impact of a modified cooperative learning methodology on the final grade distribution in a preparatory chemistry course. This course was chosen because of its historically fail/withdrawal or DFW rates, which averaged 58\% percent from 2002 to 2007.

The cooperative learning methodology used in this study was modified in several ways to address the deterrents previously described. Instead of using class time, groups were required to meet outside of traditional lectures. In order to combat the impending consequences of meeting without supervision, additional behavioral measures were put in place. First, a Cooperative Learning Workbook was developed to serve as a prompt. It detailed how to manage working in 
groups, calculate grades, and improve social functioning within the group. Second, a peer-rating system was used to minimize the "hitch hiker" effect. Finally, homework was graded and returned in a timely manner to provide feedback to the students as soon as possible. Weekly grades, which included results from a peer-rating system, were returned to the students during class, as well as through the online course management system offered by the university.

\section{Research Questions}

The purpose of this study was to explore the impact of a modified cooperative learning technique on the final grade frequencies observed in a large preparatory, college-level chemistry course designed for pre-science majors. The following research questions were explored:

1. What is the impact of using a modified cooperative learning technique on final grade frequencies in preparatory chemistry as compared to historical grade frequencies observed in the course?

2. Did the students adhere to the guidelines outlined in the Cooperative Learning Workbook for using the technique? 


\section{Literature Review}

This chapter reviews the literature on cooperative learning and its application to science courses. The first section summarizes the traditional approach to cooperative learning. The second section reviews current research using cooperative learning groups in secondary and tertiary education, with primary emphasis on applications in social and basic science courses.

\section{Cooperative Learning}

As thought leaders and prolific researchers in the area of cooperative learning, Johnson and Johnson (1994) defined it as instruction involving student teams working together to achieve a common goal by maximizing overall group and individual learning. The student teams should strive to include five components: positive interdependence, face-to-face interaction, individual accountability, collaborative skills, and group processing (Johnson, Johnson, \& Smith, 1991a). These components are detailed in Table 1.

Cooperative learning is much more than "group work," and the extent that it can be called such relies on how many of the five components are present. In addition, cooperative learning groups should be heterogeneous in composition and emphasize task and maintenance, teach social skills, process group effectiveness, and share leadership (Johnson, Johnson, Holubec, \& Roy, 1984). 
Table 1.

Five Components of Cooperative Learning Groups

Component

Description

Positive Interdependence

Face-to-Face Interaction

Individual Accountability

Interpersonal Skills

Group Processing
Task can only be completed as a group. Impetus for completing task relies on reward (participation points, bonus, etc.) or establishing operations (lack of resources or too difficult to complete individually).

Students are given time and space to meet, as well as time to seek assistance.

Group facilitates learning of all its members. Individuals are required to demonstrate mastery of the material.

Students are given opportunity to practice group skills. Feedback is provided to enhance skills such as communication, developing trust, and handling conflicts.

Students are given the opportunity to reflect on group dynamics and identify strengths and weaknesses that will impact future performance.

Cooperative learning groups range in formality from informal study groups to very structured group meetings in which each member has a specific role for a specific period of time. Johnson and Johnson (1998) outlined three approaches for implementing cooperative learning groups: formal, informal, and cooperative base.

Formal cooperative learning groups can last for several weeks or as briefly as one class meeting. Students are assigned specific roles within the group and, as the students work, the instructor moves from group to group to monitor interactions. After the work is complete, students process group functionality. Conversely, informal cooperative learning groups are 
temporary. They last for a few minutes and vary from one class meeting to the next. Informal groups help students narrow their focus on the material being presented and typically supplement more traditional instructional modalities, such as lecture. Cooperative-base groups incorporate formal dynamics but last for a longer period of time. Group membership remains stable across the semester or the year.

There are various methods for implementing cooperative learning groups. Five of the most common in the literature include Group Investigation, Jigsaw, Student Teams Achievement Divisions, Learning Together and Alone, and Teams-Games-Tournaments.

Group Investigation requires student teams to learn topics of mutual interest (Sharan \& Shachar, 1988). The groups decide how to research the topic, and then each member carries out individual responsibilities. The group comes together to summarize findings and then shares the overall group findings with the class as a whole.

The Jigsaw method (Aronson, Blaney, Stephan, Sikes, \& Snapp, 1978) divides students into groups of five. Each member is responsible for a single component of the overall lesson. Students form an expert group with members of other Jigsaw groups who were assigned the same component of the lesson. In the expert groups, students discuss how best to teach the material. Then each student returns to his or her original cooperative learning group to teach his or her part of the lesson. Grades are based on individual exam performance.

Student Teams Achievement Divisions (STAD), (Slavin, 1982) divides the class into heterogeneous groups. The teacher presents the given topic, and students work within their teams to ensure understanding by all members. Students take individual exams to test mastery. Exam 
scores are compared to past performance, and points are earned based on the degree to which individual students surpassed past performance. Finally, the points are summed to create a team score.

Learning Together (Johnson et al., 1984) incorporates all five components of cooperative learning (i.e., positive interdependence, face-to-face interaction, individual accountability, collaborative skills, group processing) to facilitate group work toward a common goal. In addition, group members divide the work evenly, provide feedback and opinions, and share in a group reward.

Teams-Games-Tournaments (TGT), developed by Slavin (1988), uses the same format as STAD, but students are divided into groups to learn the new materials. Then a student from each cooperative learning group is selected to the "tournament table.” These subgroups consist of students of comparable ability levels and change weekly. The games and tournaments replace class quizzes and are suggested for use in conjunction with midterm and final exam grades to determine final grades in the course.

Johnson and Johnson (2000) examined different cooperative learning methods and reported the results in a meta-analysis. All the previously mentioned methods had a significant impact on student achievement. Further, Learning Together demonstrated the most significant impact on achievement-related outcomes as compared to those measured in either competitive (effect-size $=.82)$ or individual (effect-size $=1.03$ ) learning situations. 


\section{Use of Cooperative Learning in Science Courses}

Cooperative learning is well documented in the literature as an effective educational practice. There are more than 375 experimental studies with more than 1,700 findings supporting its impact on social interdependence, productivity, and achievement (Johnson \& Johnson, 1998). The next section summarizes the current literature regarding the impact of cooperative learning on academic performance in social and basic science courses.

Using a repeated measures mixed model, Stockdale and Williams (2004) studied the impact of cooperative learning techniques on exam performance of low, average, and high performers in an undergraduate educational psychology course. The researchers divided the course content into three phases consisting of one content unit each. The three phases were preindividual study, cooperative learning, and post-individual study. Students $(n=378)$ were identified as low, average, or high achievers based on exam scores from the pre-individual study phase and were assigned to mixed-ability groups of five with at least one low and one high achiever. Students were awarded 10 bonus points if the cooperative learning unit exam score was at least one point higher than their individual exam scores from the pre-individual study unit.

The researchers found that both low and average achievers performed significantly better on exams during the cooperative learning phase, with increases of $11 \%$ and $5 \%$, respectively. A slight decrease in exam performance was observed for high achievers. The authors suggested that one possible reason for this decrease was that high achievers spent more time explaining concepts previously mastered rather than exploring and studying newer concepts. Another possible reason was that 10 bonus points was not enough of a reinforcer for high-achieving 
students. Overall, Stockdale and Williams (2004) concluded that cooperative learning benefited low performers the most.

Bowen (2000) summarized the analysis of 37 research studies (almost 3,500 students) examining the impact of cooperative learning on student achievement in college-level science, mathematics, engineering, and technology (SMET) courses. He reported that cooperative learning had a significant and positive effect on achievement-related outcomes, with a mean effect size of .51 and a standard deviation of 0.35 . That is, median student performance increased from the 50th percentile for traditionally instructed students to the 70th percentile for students learning using cooperative methods. Bowen also reported a significant and positive impact on student attitudes toward SMET courses. In addition, students enrolled in a course using cooperative learning techniques had a $22 \%$ greater chance of completing a SMET course as opposed to dropping it during the semester.

Bowen (2000) also conducted a meta-analysis to evaluate achievement in chemistry courses, including both high school and undergraduate students. He reviewed 15 studies (almost 1,100 students) and reported a mean effect size of 0.37 . That is, when using cooperative learning techniques, student performance was 14 percentile points higher than that of students taught by traditional methods. Dinan and Frydrychowski (1995) reported increased class attendance and richer classroom discussions as a result of using cooperative learning groups in organic chemistry with undergraduate students. First-year undergraduate organic chemistry students served as participants. Groups were assigned a lesson and then given the first 10 minutes of the following class to discuss the core topics before taking a weekly mini-test. These mini-tests were first taken individually and then as a group. Scores were returned immediately and focused the 
discussion for a brief lecture. Students also took three, hour-long exams across the semester using the same methodology. Although differences were not statistically significant, Dinan and Frydrychowski reported comparable final exam scores when using cooperative methods as compared to traditional lecture instruction, with the added benefit of covering larger amounts of material and highly engaged students.

Investigating the impact of cooperative learning on undergraduate understanding of chemical equilibrium, Doymus (2007) compared two groups' achievement on the Chemical Equilibrium Achievement Test (CEAT). One group used individual learning methods, and the other group used the Jigsaw method. The CEAT divides the topic of chemical equilibrium into four modules (A, B, C, and D). Jigsaw home groups of four were formed so that each student was assigned as the expert for one of the four modules. The experts learned the module by meeting with other students in the class assigned as experts to the same module. After learning the material, the expert taught the module to the other three members of his or her home group. Doymus found that students who used the Jigsaw technique scored better on the CEAT than those who used individual learning methods.

Lyon and Lagowski (2008) investigated the use of facilitated small-group learning on overall grades and exam scores. Participants included 475 undergraduates enrolled in a large introductory chemistry course (the second course in a two-semester general chemistry sequence). Peer teaching assistants were trained and assigned to lead small-group learning sessions outside of class time. Students were encouraged to attend, but participation was ultimately voluntary. In addition to sharing the benefits associated with the group learning, bonus points were offered as incentives for participation. Students could pick 1 of 11 time slots to attend the group session. 
Lyon and Lagowski compared the student exam scores and overall course grades to those who elected not to participate. They observed significant differences in both mean exam scores and course grades. That is, students who participated earned higher exam scores on average, as well as higher overall course grades. This study was different from traditional cooperative learning grouping because each small group was led by a peer teaching assistant. These assistants were trained on the Socratic Method and practiced facilitation in preparation for these groups. Therefore, this method does not comply with the essential features of cooperative learning groups described by Johnson et al. (1984).

Chapman and Blemings (2006) observed overall improvements in student achievement and higher pass rates in course sections where students worked cooperatively. Eighty-seven percent of students $(n=241)$ passed an undergraduate biochemistry course using cooperative learning methodology compared to only $71 \%$ of students in a control group.

Cooperative learning has been used successfully in non-lecture-based courses as well. Smith, Hinckley, and Volk (1991) used the Jigsaw method to teach the lab portion of an introductory chemistry course. One laboratory section used traditional procedures where each student $(\mathrm{n}=31)$ worked through the lab and completed the assignments based on procedural instructions from the instructor. Another laboratory section used cooperative learning methods. Students ( $n=21)$ were put into groups of three to complete a three-part lab. The students in the cooperative learning section demonstrated higher achievement on lab quizzes than the students who worked alone. Further, Smith et al. noted that weaker students in the cooperative learning group scored higher than those in the alone section. 
In addition to traditional student performance measures such as achievement, students also reported that working in cooperative learning groups enhanced critical thinking skills. Hager, Sleet, Logan, and Hooper (2003) assigned first-year students to small, mixed-ability groups to cooperatively solve open-ended physics and chemistry problems. The problems were designed to incorporate critical thinking and problem-solving skills to answer challenging science questions with the collaborative working skills needed to succeed in a science career. The groups consisted of three members, typically of the same sex. A handout was distributed to encourage common concern for the success of other group members and a shared leadership responsibility. Leadership roles were assigned and rotated with each assignment. The impact of the group work on the critical thinking needed to solve the science problems was qualitatively assessed through a questionnaire, discussions with the students, and comments from tutors. Overall, students reported enhanced critical thinking skills as a result of working in the small groups.

Madhu, Schaefer, and Morlino (2008) reorganized the structure of a general chemistry course to include a group problem-solving component. Instead of four large lecture sections of 90 students and optional recitation, the lecture portions were collapsed to two sections of about 180, and a mandatory recitation was added (four recitations of 45 students each). Within each recitation, heterogeneous groups were created based on mathematics SAT scores. Teaching assistants helped with grading and facilitation. Students completed homework problems prior to meeting to prepare for recitation group work. The group work problem sets had a higher level of difficulty than homework problems in an attempt to prompt discussion and critical thinking. The revised course format was compared to the traditional lecture format using two-sample $t$-test 
analyses. Significant differences in exam averages were reported. That is, students averaging $60 \%$ or below on exams decreased from $27.5 \%$ to $19 \%$.

Heller, Keith, and Anderson (1992) evaluated the impact of using a five-step problemsolving strategy in cooperative learning groups to solve physics problems. One-hundred and twenty undergraduates were assigned to mixed-ability learning groups and provided instruction on the problem-solving strategy. Specifically, Heller et al. found that the group solutions to the physics problems were better than the individual solutions of the highest performing student in each group, and individual problem solving improved over time. In addition, the solutions were more expert-like as compared to those submitted by students in the control group.

Describing her experiences using cooperative learning at Clemson University, Cooper (1995) detailed the advantages of using cooperative learning in large enrollment courses. Advantages included increased responsibility for learning and development of higher-level thinking skills. That is, thinking skills were furthered because group work minimized distractions and increased time spent working on more complicated problems—-truly learning concepts through synthesizing information versus rote memory. Cooper also stated that students reported higher levels of satisfaction with learning and were more likely to graduate as a result of working in cooperative learning groups. In addition to these general benefits, Cooper detailed specific benefits for large enrollment courses such as increased participation rather than limited participation by a few more confident students. Cooper also discussed many of the perceived deterrents to implementing cooperative learning techniques. Three commonly perceived deterrents included inability to cover the material, lack of control, and addressing the "hitch hiker" problem. 
Using multimedia demonstrations, examples, or simulations to elaborate on lecture topics, Pence (1993) observed increased class participation, student interaction, and class cohesion when students worked cooperatively. He also observed lower frequencies of students who withdrew from the course.

Peer-Led Team Learning (PLTL) is a group learning methodology also evaluated in the literature. PLTL uses students who have successfully completed the course material in the past as team leads. The students are trained in group dynamics and then asked to lead a group of four to eight less experienced students through focused study sessions. The sessions are typically voluntary and are held outside of class time. PLTL was originally developed at the City College of New York to promote problem-solving in general chemistry (Gosser \& Roth, 1998), There is strong support for PLTL yielding higher retention rates and levels of critical thinking in science courses at the college-level (Lewis, 2011; Quitadamo, Brahler, \& Crouch, 2009). These results have been observed regardless of gender, ethnicity, or class standing.

\section{Conclusion}

This literature review examined the impact of cooperative learning methods used in high school and college science courses, and found results consistent with multiple cooperative learning meta-analyses. When cooperative methods were implemented versus traditional instructional methods, increased academic achievement, attitudes, critical thinking, problem solving, class participation, student interaction, and class retention rates were observed. The majority of the studies reviewed employed the critical features of cooperative learning described by Johnson et. al. (1984) even if not discussed or labeled directly. The studies used heterogeneous groups, emphasized a task, taught social skills, encouraged group processing, and 
shared leadership. Many of the studies also included components meant to encourage students to take interest in peer performance in addition to their own. Also, true comparison groups were used whether within or between subjects to evaluate the impact of the cooperative learning on student functioning.

A common weakness noted in this collection of research was that few studies attempted to consider implementing cooperative learning in a new or different way. Chapman and Blemings (2006) successfully addressed the hitch-hiker deterrent with the use of a peer-rating system. In addition, a couple of the other studies added a facilitator component to help group functioning and processing (Lyon \& Lagowski, 2008; Madhu, Schaefer, \& Morlino, 2008). The remainder of the studies replicated what was already a proven strategy for teaching. Few if any truly addressed why so few professors use cooperative learning at the high school and college level.

Despite the benefits students experienced in cooperative learning groups, the majority of instructors do not implement the methodology today. Instructors may be hesitant because it is a time-consuming teaching strategy. One option may be to arrange such experiences outside of regular class meeting times. There is limited research assessing how to modify traditional cooperative learning techniques so that students benefit from the tenets of the methodology outside of class time. This research study extended the current literature by examining one way to supplement traditional cooperative learning techniques by incorporating a more behavioral methodology in an attempt to assess the efficacy of cooperative learning techniques when used outside of class time. Specifically, a Cooperative Learning Workbook was provided to prompt the behavior involved in completing weekly homework in assigned groups. In addition, several 
feedback systems were put in place to provide students with timely appraisals of their work. Using a methodology similar to Chapman and Blemings (2006), this study incorporated individual accountability and incentives in addition to group accountability and incentives by requiring the students to rate one another on weekly contributions.

\section{Method}

\section{Participants}

Participants in this study were 334 undergraduate students between the ages of 17 and 31 years ( $M=20$ years, $S D=2.2)$ enrolled in preparatory chemistry during the spring 2008 semester at a university located in the United States. The course was designed to prepare students for introductory chemistry—a full-year general chemistry course taken by science and engineering majors. The preparatory course was a one-semester, two credit-hour course focused on chemical problem solving. Students whose standardized test scores were not high enough to directly enroll in introductory chemistry were required to pass the preparatory course with a minimum grade of a C. In order to qualify for introductory chemistry as a first-semester freshman, students needed to obtain a minimum math ACT score of 26 or a minimum SAT score of 600 . Students also could qualify by scoring a 24 on the university's Quantitative Reasoning Assessment which includes questions on basic algebra and calculus readiness. According to demographic data provided by the students completing the course, $36 \%$ percent of were male, $52 \%$ were female, and 11\% did not report gender. Eighty-four percent were Caucasian, 7\% African American, 3\% Asian, 3\% Hispanic, 2\% Middle Eastern, and 1\% reported other. The majority, 59\%, were freshman students followed by sophomores (31\%), juniors (7\%), and seniors (3\%). On average, 
the students were enrolled in 14.71 credit hours $(S D=2.59)$ with $51 \%$ of the students repeating the preparatory chemistry course.

All sections offered in the spring 2008 semester were included in the study and were taught by the same instructor. Historical data indicate spring sections tend to have higher DFW rates than do fall semesters. The three sections represented students who typically enrolled in preparatory chemistry. That is, all students needed to eventually enroll in introductory chemistry to fulfill their major requirements, and their standardized test scores were below 26, 600, or 24 for the ACT, SAT, or University Quantitative Reasoning Assessment, respectively. Setting

This research was conducted at a public, land-grant university with an enrollment of approximately 28,000 students at the time of the study. The institution is designated as a Research High Activity University by the Carnegie Foundation for the Advancement of Teaching and is accredited by the North Central Association of Colleges and Schools. It offers 185 undergraduate and graduate degree programs, including agriculture, arts, business, consumer sciences, creative arts, dentistry, economics, education, engineering, forestry, human resources, journalism, law, medicine, natural sciences, nursing, pharmacy, social sciences, and sport sciences. 


\section{Measures and Grading}

The preparatory chemistry course was structured around 13 quizzes containing competency question-sets and mastery questions. Competency question-sets were graded pass/fail, but mastery questions were worth 10 points each. Students had to pass all competency question-sets independent of mastery points. Therefore, if a student failed a competency question-set, he or she retook the quiz for that section until he or she passed. In addition, students were assigned 10 homework sets during weeks 3-12 of the semester. Each homework set was worth a maximum of 10 points, for a total of 100 total points. In previous semesters, students were strongly encouraged to do the homework sets in preparation for weekly quizzes. In this study, the homework sets were a mandatory component of the course and were required to be completed in assigned groups. Final grades were computed by summing the points earned on the 13 quizzes, the group homework, attendance, and the final exam. There were 1,000 points possible in the course. In addition to the student grades, a peer-rating scale designed to measure individual contribution scale (described in the procedure section) was created and used to measure individual contribution to the group homework assignments.

Finally, a group homework survey (Appendix A) was developed to gather information on student demographics, group functioning, homework completion, and student attitude toward working in groups. The survey was administered during the last week of classes. Although some of the items were beyond the scope of this dissertation, the upfront portion was used to collect demographic information and questions $3-6,10,12-14$, and 16 - 21 were used to describe student participation, group functioning, adherence to the methodology, and overall reaction to the benefits of working in groups. 


\section{Procedure}

During the first day of class, students were informed of the mandatory cooperative component of the course by verbal announcement and written notification included in the course syllabus (Appendix B). Students were instructed to work individually to complete assignments and to study for quizzes for the first two weeks.

On the first day of class in the third week of the semester, the primary researcher used class time to explain the cooperative learning procedures, distribute the Cooperative Learning Workbook (Appendices C and D, respectively), and assign groups. Groups were announced in class and members were given time to meet and exchange personal information. All students also received email notification of their group assignment.

Group assignment was determined using a methodology similar to that described by Chapman and Blemings (2006) and Stockdale and Williams (2004). Students were ranked as an A, B, C, D, or F using the average of their first and second quiz grades. Next, they were randomly divided into heterogeneous groups, including one A, B, C, D, and F student to compose a five-member, mixed-ability group. Effort was made to balance the group in terms of gender as well. Given the disproportionate number of Caucasians enrolled in the course, the groups were not balanced in terms of ethnicity, however. For tracking and grading purposes, each group was assigned an identification number. The purpose of using heterogeneous groups was to balance group ability within each section. All of the literature examined supports the use of heterogeneous groups as opposed to homogeneous ones. That is, researchers agree that group composition should be mixed in terms of ability, ethnicity, and sex. The use of heterogeneous groups is highly correlated with increased understanding and long-term retention because 
participants engage in more elaborate thinking skills and practice by sharing and receiving multiple perspectives (Cohen, 1994; Johnson, Johnson, \& Smith, 1991b; Slavin, 1983). In addition, Baloche (1998) offered support stating that mixed group composition is associated with decreases in the influence of biased expectations used to describe students prior to performance in terms of ability and social identities. Further, mixed groups allow high-achieving members to act as role models for lower achieving students and prepare students for life beyond school (Jacobs, Power, \& Inn, 2002).

On a weekly basis, students were expected to meet in assigned groups outside of class time to complete homework assignments. Using the procedures outlined in the Cooperative Learning Workbook, the groups were expected to:

- Meet face-to-face each week to work as a team to complete the assigned homework

- Assign roles (Team Leader, Recorder, Teacher, Student, and Task Manager) and responsibilities each week

- Show all work and answers for each homework problem

- Use a different color ink to grade the group's homework after completing the problems

- Show revisions using a different color ink if answers were incorrect

- Make photocopies so that each member of the group had access to the exercise sets in preparation for the weekly quiz (before handing the homework assignment in for grading)

- Use active listening skills, as well as other social skills to work as a team

- Process the group’s functioning during the last five minutes of each meeting asking questions such as:

- Did we accomplish our goals? 
- Do all members understand the material?

- Did we maintain positive interactions within the group?

- Did we solve problems in a systematic manner?

In addition to weekly procedures and grading, the Cooperative Learning Workbook included sections that further explained roles and responsibilities, as well as social skills.

The cooperative learning project consisted of 10 group homework assignments and was worth 100 points, or $10 \%$ of the final preparatory chemistry grade. Each student's grade on each cooperative learning assignment was determined by two factors: group performance on the weekly homework assignment and individual contribution to the group. Homework deadlines were announced in class well in advance of the due dates. The group turned in one copy with the assigned group number written in the top corner. Based on accuracy, the group earned a maximum of 10 points for each assignment. Homework assignments were graded by the course professor or graduate teaching assistants, and feedback was provided within one week. Each week students also were required to rate their group members' individual contribution to the homework assignment by completing a confidential peer-rating scale (Table 2). 
Table 2.

Individual Contribution Rating Scale

\begin{tabular}{|c|c|}
\hline Individual Rating & Behavioral Definition of Each Individual Rating \\
\hline 0 = Did Not Participate & $\begin{array}{l}\text { - Member did not show up to the group meetings. } \\
\text { - Member attended group meetings but did not contribute to the } \\
\text { homework assignment in any way. }\end{array}$ \\
\hline 1 = Below Expectation & $\begin{array}{l}\text { - Member showed up but did not contribute assigned portion(s) of the } \\
\text { homework. } \\
\text { - Member showed up but did not fulfill assigned role. }\end{array}$ \\
\hline 2 = At Expectation & $\begin{array}{l}\text { - Member attended group meetings. } \\
\text { - Member completed his or her portion(s) of the homework } \\
\text { assignments. } \\
\text { - Member fulfilled assigned role. } \\
\text { - Even though the member may be having difficulty with the material, } \\
\text { he or she still attempted to learn and participate in the group. }\end{array}$ \\
\hline
\end{tabular}

Based on the rating received each week, the points earned on the cooperative learning assignment either stayed the same or decreased. If two or more ratings of a "0" were given, a student received $0 / 10$ as his or her individual homework score. If two or more ratings of a "1" were given, the student's homework grade was reduced by $50 \%$. Finally, if two or more ratings of a "2" were given, the student's homework grade stayed the same. In the case of a tie, the higher rating score was used.

Examples of all possible grading scenarios were detailed in the Cooperative Learning Workbook. Rating scales were due to the group's assigned email address each week and were 
kept confidential at all times. A sample email was provided as a template. The primary researcher sent an email reminder the morning the rating scales were due to encourage students to participate. Upon receipt of the rating scales, the primary researcher responded to each student via email to verify receipt of the rating scores. Any student who did not provide a rating for each member of his or her group received a zero on the weekly homework assignment.

Individual homework scores were posted to the university's course website. Students used the course website to access course and grade information on a regular basis. The section email addresses were also used to monitor group functioning. The primary researcher used the email accounts to issue secondary reminders regarding the ratings scales, follow up on group problems, and send updates regarding grade postings to the course website. The email interaction provided an opportunity to monitor the implementation of the procedures outlined in the Cooperative Learning Workbook.

\section{Data Analyses}

To assess the impact of the modified cooperative learning methodology on both passing and DFW grade distributions, a chi-square test for goodness of fit was conducted. The chi-square tested the null hypothesis that the frequency distribution of letter grades (A, B, C, and DFW) observed during the spring 2008 semester would not be different from the frequency distributions of letter grades observed historically in preparatory chemistry.

In addition, the impact of the modified cooperative learning groups on student DFW rates was assessed by comparing trends in descriptive data, such as differences in the frequency and 
percentage of final grades earned by students during the spring 2008 semester and a sample of those earned during the spring 2006 and 2007 semesters.

Open-ended survey data were collected through a group homework survey. The data were used to descriptively assess adherence to the modified cooperative learning technique in three areas: group functioning, group homework completion and participation, and attitude toward group homework. The survey was created by the primary researcher with the aid of a committee who edited and refined the survey items. The committee consisted of the director of the preparatory chemistry department, an instructor with 10 years of preparatory chemistry teaching experience, and a doctoral-level educational and school psychologist. Although unable to move beyond content validity using more robust analyses, Cronbach’s alpha coefficients were computed to demonstrate internal consistency reliability.

\section{Results}

This chapter describes the results of the study in three sections. The first section shares the known historical data for DFW frequencies in preparatory chemistry and then compares the data to those collected during the spring of 2008 when group homework was a mandatory component of the course. A chi-square goodness-of-fit analysis was conducted to test the null hypothesis that the final grade frequencies observed in the spring of 2008 were no different than those observed historically in preparatory chemistry. The results of the analysis are explained in

section two. Finally, section three describes the results of the group homework survey in terms of group participation, group functioning, and attitude toward group homework. 
Over the six-year period from 2002 to 2007, DFW percentages earned by students in preparatory chemistry averaged $57.50 \%$. During spring semesters, the DFW rates tended to be higher than those observed in the fall. Figure 1depicts this trend with DFWs averaging as high as $70 \%$ in the spring of 2007. During this same six-year period, freshman enrollment at the university increased 9\%. It was assumed the additional students enrolled were weaker in ability and increased enrollment (7.6\%) in preparatory chemistry course supported this claim (RichardsBabb, Drelick, Henry, and Robertson-Honecker, 2011).

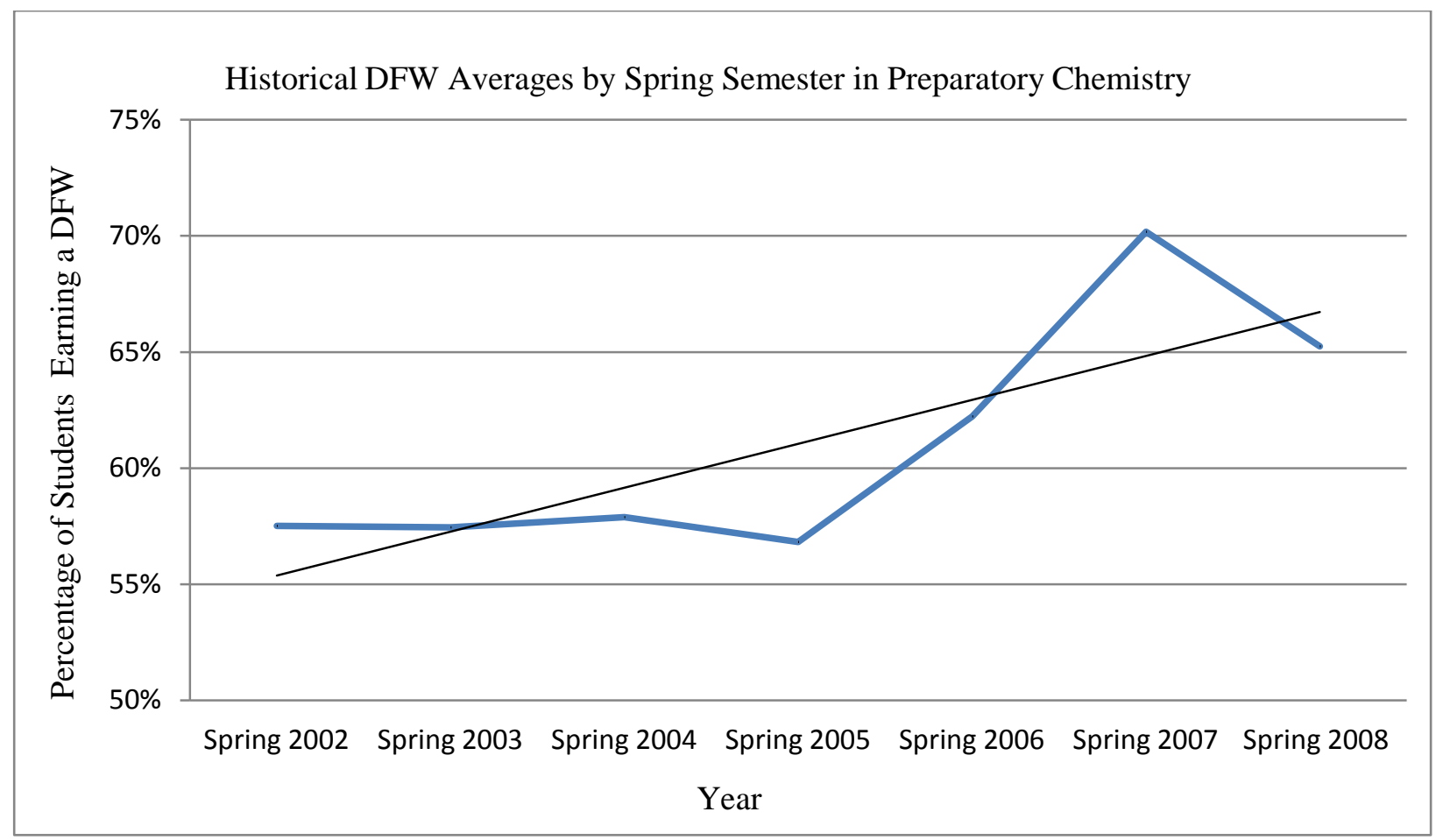

Figure 1. Six-year historical DFW percentages observed in preparatory chemistry.

In the spring of 2008, three sections of a college-level preparatory chemistry were offered. All students enrolled were asked to complete mandatory homework in groups outside of class time using a cooperative learning methodology. The impact of the modified technique on 
final grade frequencies was examined in this study. Table 3. lists the final grade frequencies and percentages observed for all 334 students enrolled in the course.

Table 3.

Final Grade Frequencies Observed During Study

\begin{tabular}{|c|c|c|c|c|c|c|}
\hline $\mathrm{N}=334$ & A & $\mathbf{B}$ & $\mathbf{C}$ & $\mathbf{D}$ & $\mathbf{F}$ & $\mathbf{W}$ \\
\hline Frequency of Final Grades & 18 & 39 & 68 & 47 & 74 & 88 \\
\hline Percentage of Final Grades & $5 \%$ & $12 \%$ & $20 \%$ & $14 \%$ & $22 \%$ & $26 \%$ \\
\hline Frequency of Students Earning a Passing Grade & & 125 & & & & \\
\hline Percentage of Students Earning a Passing Grade & & $37 \%$ & & & & \\
\hline Frequency of Students Earning a Failing Grade & & & & \multicolumn{2}{|c|}{121} & \\
\hline Percentage of Students Earning a Failing Grade & & & & \multicolumn{2}{|c|}{$36 \%$} & \\
\hline
\end{tabular}

The frequencies and percentages in Table 3 were compared to a sample of final grade frequencies and percentages observed in the same preparatory chemistry course during the previous two spring semesters (2006 and 2007 combined). During these semesters, homework was a discretionary practice encouraged by the faculty, but not graded or factored into the final grade calculations. Also, no cooperative learning methods were used during these two semesters. Using the modified cooperative learning technique, an increase in passing grades was observed. That is, there were 6\% more passing grades in 2008 (4\% more As, 1\% fewer Bs, and 3\% more Cs earned by students). Although there were $16 \%$ fewer withdraws from the course, there were increases in failing grades with 3\% more Ds and 6\% more Fs. See Figure 2 for a more detailed comparison of the final grade frequencies and percentages. 


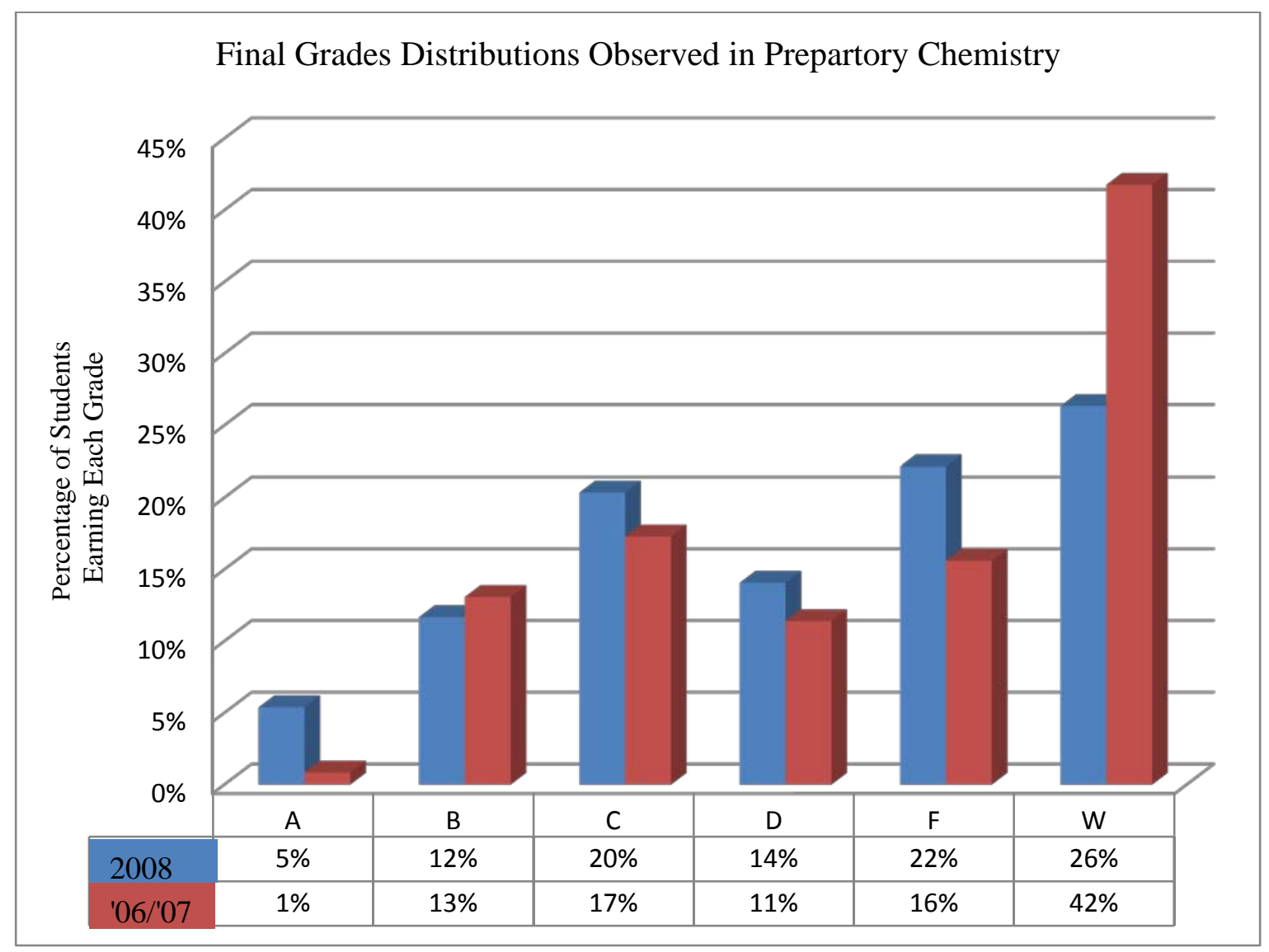

Figure 2. A comparison of cooperative learning final grades to historical final grades.

A chi-square test of goodness-of-fit was performed to test the null hypothesis:

$\mathrm{H}_{0}$ : The frequency distribution for the spring 2008 final grades in preparatory chemistry is no different from the historical final grade frequency distributions.

The analysis showed the final grade frequency distributions were significantly different when students worked in groups to complete homework using a modified cooperative learning techniques, $\chi^{2}(1, \mathrm{~N}=334)=48.1302, p<.005$. Refer to Table 4 . 
Table 4.

Chi-Square Test of Goodness-of-Fit

\begin{tabular}{lll}
\hline \multicolumn{1}{c}{$\begin{array}{c}\text { Passing Grade } \\
\text { (A, B, or C) }\end{array}$} & DFW \\
fo & 125.0000 & 209.0000 \\
fe & 74.0000 & 163.0000 \\
fo- $\mathbf{f e}$ & 51 & 46 \\
$(\mathbf{f o}-\mathbf{f e})^{2}$ & 2601 & 2116 \\
$\left((\mathbf{f o}-\mathbf{f e})^{2} / \mathbf{f e}\right.$ & 35.1486 & 12.9816 \\
$\chi^{2}=\sum\left((\mathbf{f o}-\mathbf{f e})^{2} / \mathbf{f e}\right)$ & 48.1302 & \\
$\mathbf{d f}=\mathbf{1}$ & & \\
\hline
\end{tabular}

The survey used in this study was created with the intent of measuring constructs related to the implementation of the modified cooperative learning technique. The survey consisted of 21 Likert-type questions about group functioning, group homework participation, and attitude toward group homework. In addition, the survey asked 12 general information questions to solicit demographic data and five open-ended questions to gather feedback from the students. Of the 334 students enrolled in the course, 188 completed the survey which is a 56\% response rate. Considering only those students who did not withdraw from the course, 188 of 246 completed the survey which is a $76 \%$ response rate.

Group Functioning. When asked to describe the extent to which their group reviewed and revised homework assignments before submitting them each week, $78 \%$ of reported they did so most of the time if not all of the time. Role assignment, overall, was not practiced with 52\% claiming they never assigned roles and $29 \%$ reporting they did so only occasionally. Similar 
responses were made about alternating role assignment with 56\% reporting they never alternated roles and $29 \%$ doing so only occasionally. In terms of processing group functioning, it appeared that 54\% did not and 46\% did. Overall, the group homework survey indicates that the groups did not use the cooperative learning workbook to help improve group functioning, but did review and revise homework regularly.

Group Homework Completion and Participation. Eighty percent of the students reported completing at least seven of the group homework assignments with 57\% reporting their group completed all 10 assignments. However, $73 \%$ of the groups rarely (less than 4 assignments) completed additional practice problems other than those assigned. When asked to describe their participation in the group work, 48\% reported contributions to all 10 assignments and 32\% reported participation in at least seven assignments. Only 4\% did not participate in the group work at all. When asked how often they rated their peers, $81 \%$ did so for at least seven of the assignments. Overall, the group homework survey indicates that the groups met and the majority of the students contributed to the assignments in some way.

Attitude toward Group Homework. The majority, 64\%, of students claimed they experienced some benefits from working in groups with 23\% reporting they experienced a lot of benefit. Similarly, 65\% reported that the group work was worth the effort with $20 \%$ saying it was well worth the effort. When asked how they felt about group work and their intentions to take another course including a group work component, 58\% disliked the group work and 50\% reported it unlikely that they will take another group work course in the future. Finally, 50\% felt the group work helped their grade in preparatory chemistry, but 20\% reported the group work component actually hurt their grade in the course. Overall, student attitude toward group work 
was mixed with half of the students acknowledging benefits from working in groups and felt it impacted their preparatory chemistry grade positively.

Five open-ended questions were included in the survey to further explore attitude toward group homework. Specifically, the students were asked to consider the following:

1. Please indicate specific things that you like about working in groups.

2. Please indicate specific things that you didn't like about working in groups.

3. How would you change the group work in Chemistry 110.

4. How did you feel about rating your peers each week using the rating scales?

5. Please list any additional comments that you would like to make regarding your experience with cooperative learning.

Consistent themes were noted in the open-ended data. Overwhelmingly, the students reported that working in groups increased their understanding of the problems and that it was helpful to have different perspectives and others to work with to complete the questions sets. Some students did, however, take the opportunity to express a strong dislike for group work despite increases in understanding. When asked what they did not like about working in groups, students agreed that meeting outside of class time was difficult given the number of schedules each group needed to coordinate. Students also reported that the sizes of the groups were too big and they would have preferred to have a smaller group size of three. In addition to smaller group size, students also recommended adding a lab component to the course which the groups could use to complete the homework. Overall, students reported the peer-rating scale to be an afterthought. Many commented that they regularly forgot to submit the peer rating and often made them up. 
When asked for suggestions on how to change the peer rating scales, many students recommended omitting them in the future.

A Cronbach’s Alpha Coefficient was calculated to measure the internal reliability of the subsets of questions associated with each of the three constructs: group functioning, participation, and attitude. Eighteen of the 21 items comprised the three subsections of the survey. Questions 3-6 were designed to collect information about adherence to the Cooperative Learning Workbook which provided specific guidelines for effective group functioning $(\alpha=.74)$. Questions 10, 12 - 14 were asked to gauge the extent to which the students participated in the group homework $(\alpha=.59)$. Finally, questions $17-21$ included questions measuring the extent to which the students felt that group homework was beneficial and worth the effort $(\alpha=.82)$.

George and Mallory (2003) describe internal consistency as excellent $(\alpha \geq .9)$, good $(.9>\alpha \geq .8)$, acceptable $(.8>\alpha \geq .7)$, questionable $(.7>\alpha \geq .6)$, poor $(.6>\alpha \geq .5)$, and unacceptable $(.5>\alpha)$. The Cronbach Alphas are summarized in Table 5. 
Table 5.

Internal Reliability of the Group Homework Survey

\begin{tabular}{|c|c|c|c|}
\hline \multirow[t]{2}{*}{ Cronbach's Alpha } & \multirow[t]{2}{*}{ Mean } & Standard & Number of \\
\hline & & Deviation & Items \\
\hline
\end{tabular}

Group Functioning $\quad \alpha=.74$

Acceptable

Group Homework $\quad \alpha=.59 \quad \mathrm{M}=$

Participation

Poor/Questionable $\quad 14.526$

$S=3.196$

4

Attitude toward

$\alpha=.82$

$M=$

Group Homework

Good

13.803

\section{Discussion}

Cooperative learning is a well validated educational practice shown to improve academic performance, problem solving, creativity, and social skills (Johnson \& Johnson, 1989). Years of empirical research demonstrate the effectiveness of the methodology across disciplines, levels of education, gender, and ethnicity. Despite the convincing body of evidence in favor of cooperative learning, lecture still dominates collegiate learning as the primary mode of teaching. This study attempted to modify traditional cooperative learning techniques by considering some of the most noted reasons for not using or trying the technique. The modifications were meant to address those concerns, but still fulfill the critical components which discriminate cooperative learning from group work. As detailed in Table 1, the critical components are positive 
interdependence, face-to-face interaction, individual accountability, interpersonal skills, and group processing (Johnson, et. al., 1984). Preparatory chemistry students were asked to participate in this study because of historically high DFW rates observed in the course. From 2002 to 2007, more than half of the students enrolled failed or withdrew from the class with at least one semester having a 70\% DFW rate.

The primary research question asked if the final grade frequencies observed in 2008 while using the modified cooperative learning methodology were different from historical final grade frequencies. The chi-square goodness-of-fit analyses rejected the null hypothesis and concluded that the two frequency distributions were in fact different. The descriptive data collected from the final grade archives as well as the group homework survey confirmed that more students earned passing grades in the spring 2008 than those in the sample historical data. The findings of this study suggest that the use of the modified cooperative learning technique may have helped students practice the chemistry problems, prepare for the quizzes, and ultimately better understand the material resulting in a greater number of passing final grades and therefore fewer DFW grades. Although there were increases in Ds and Fs, 3\% and 6\% respectively, there was a larger decrease in withdraw frequencies with $16 \%$ fewer students dropping the course. This finding further supports the impact of the modified cooperative learning component on the final grade distribution as the methodology has also been referenced as a key contributor to student retention (Cooper, 1995). Although more students earned Ds and Fs, this may be preferential to taking a "W" or withdraw from the course. Continued financial aid is awarded as long as students make satisfactory progress toward their degree. Satisfactory academic progress is measured by dividing successful courses completed by courses attempted. 
If a student's completion ratio falls below $67 \%$, he or she may no longer be eligible for financial assistance.

Another plausible explanation for the difference in the final grade frequency distribution is the mere inclusion of a graded homework component. It is known that preparatory chemistry students who regularly completed weekly homework assignments fare better in the course, historically. This is consistent with current research suggesting that the inclusion of a graded homework component based on completion and accuracy is enough to improve academic performance on quizzes at the college level (Rehfeldt, Walker, Garcia, Lovett, \& Filipak, 2010; Ryan \&d Hemmes, 2005). Therefore, the current study cannot claim with certainty whether the cooperative learning methods, the mandatory homework, or another unidentified variable impacted the differences observed in the final grade distribution.

The secondary research question posed in this study involved the implementation of the modified technique, which is detailed in the cooperative learning workbook. Specifically, it is important to ascertain whether the students followed the criteria outlined in the workbook. If so, there is further support for the claim that the modified cooperative learning technique was responsible for the increases in passing grades and decreases in DFWs. Considering the findings from the group homework survey, however, at least half of the students reported that their groups did not engage in some of the behaviors critical to creating effective cooperative learning groups. Group processing is one of the components necessary to promote the benefits of cooperative learning (Johnson et al., 1984) and the group homework survey results revealed that the majority of students did not assign key roles, alternate those roles, or process group functioning. Although the students did report that their groups regularly checked and revised their work as a group prior 
to handing in the assignment for a grade. These data are helpful in considering potential reasons why the cooperative learning groups did not have a more dramatic impact on final grade frequencies. If at least half of the students did not choose or understand how to work cooperatively, the benefits would be reduced for all members. Another consideration for the reported lack of adherence to the cooperative learning methodology is the overreliance on the cooperative learning workbook as a standalone tool. If the students were absent during the introduction of the group work concept, reading the workbook became a more discretionary practice. Students attending the overview were given time to read over it as well as listen to the introductory presentation covering the highlights from the workbook. Future studies may consider using a Peer-Led Team Learning approach in which an undergraduate teaching assistant could serve as a member of each group to ensure content is practiced correctly and adherence to the cooperative learning methodology.

Overall, the findings from this study were consistent with the majority of the existing cooperative learning literature (Bowen, 2000; Johnson, Johnson, \& Smith, 1991a). The data suggest that academic performance improved as evidenced by increased numbers of passing grades observed at the end of the spring 2008 semester. With a few modifications to the methodology, this study replicated the findings of Chapman and Blemings (2006) who also observed increases in passing grades for students enrolled in an undergraduate biochemistry course when using cooperative learning methods. However, the results may not be practically significant enough to offset the considerable amount of resources necessary to manage the program. The methodology including the peer-rating component may create another deterrent to using cooperative learning in the future. The peer-rating system was implemented to reduce the likelihood of the hitch-hiker effect, but was extended to also provide feedback to the students 
regarding the ratings, participation, and issue resolution. This component was a very time consuming task taking up to 20 hours per week. An instructor or professor would need teaching assistants to regularly implement such a design. The benefits and tradeoffs need to be more thoroughly researched to make an informed decision as to whether or not the peer rating scale is a worthwhile addition. Or, future research may also consider collecting this information differently. For example, they can include the peer-rating scale on the bottom of the weekly quizzes or send an electronic survey to the student each week tied to a score. As used in the current study, there were no incentives for completing the peer-rating scale on time and with integrity. Many students admitted to making up the ratings in the open-ended survey items.

\section{Limitations and Implications for Future Research}

This study is first and foremost confined by its design and statistical analyses. The use of nominal data and the chi-square goodness-of-fit analysis limits the ability to attribute the findings to cooperative learning. Future research designs may consider replicating the current study by supplementing the design with a control and/or alternative group work situations. For example, the addition of an in-class cooperative learning condition and a cooperative learning homework lab condition may provide better insight into the need to limit or take advantage of group work outside of class lecture. This inclusion of a lab component was also encouraged by the students in the group homework survey. This is important to know as many instructors cite that the use of class time for groups to meet is a major deterrent to using cooperative learning.

Another weakness of this study that will need to be addressed in future work was the limited use and reference to the cooperative learning workbook. Although the workbook was discussed in detail during the third week of the semester, some students reported that they did not 
read or use it. Future studies requiring the groups to meet outside of class time will need to consider alternative ways to ensure understanding and use of cooperative learning methods such as direct observation and assessments. This is important to ensuring that the groups are working cooperatively and therefore experiencing the benefits the pedagogy. This leads to another interesting implication not addressed in this study. It is also important to have a system in place to identify dysfunctional cooperative learning groups early in the process. Given the population used in this study, there may also be value in defining what constitutes a dysfunctional cooperative learning group when dealing with new, at-risk college students. An alternative worth considering would allow educators to see leading indicators of progress as opposed to waiting for more lagging measures such as test performance spaced out across a semester. Future studies should devote more time preparing the students in the essential components of cooperative learning. It may be worthwhile to add a quiz on the cooperative learning process, social skills, and peer-rating system. The points earned from the quiz could be factored into final grades.

Finally, the inability to demonstrate the validity of the group homework survey beyond content value was also a weakness. The current study cannot truly be confident in the qualitative data collected and therefore cannot state with confidence that the survey tool measured what was intended, the implementation of the modified cooperative learning technique. The reliability of the survey was also questionable for the subset of questions designed to measure homework participation and completion. Future studies may consider using an already validated and reliable instrument to survey the students before and after the implementation of the study. A further investigation of the questionnaire used by Hager et. al. (2003) may be useful to future researchers. 


\section{References}

Aronson, E., Blaney, N., Stephan, C., Sikes, J., \& Snapp, M. (1978). The jigsaw classroom. Beverly Hills, CA: Sage.

Baloche, L. A. (1998). The cooperative classroom: Empowering learning. Upper Saddle River, NJ: Prentice Hall.

Bowen, C. W. (2000). A quantitative literature review of cooperative learning effects on high school and college chemistry achievement. Journal of Chemical Education, 77(1), 116119.

Chapman, P., \& Blemings, K. (2006). Improving retention rates in biochemistry: A quasiexperiment. Radical Pedagogy, 8(1). Retrieved from http://radicalpedagogy. icaap.org/content/issue8_1/chapman.html

Cohen, E. G. (1994). Designing groupwork. New York, NY: Teachers College Press.

Cooper, M. M. (1995). Cooperative learning: An approach for large enrollment courses. Journal of Chemical Education, 72(2), 161-164.

Dinan, F. J., \& Frydrychowski, V. A. (1995). A team learning method for organic chemistry. Journal of Chemical Education, 72(5), 439-441.

Doymus, K. (2007). Teaching chemical equilibrium with the jigsaw technique. Research in Science Education, 38(2), 249-260. 
Ediger, M. (2001). Learning opportunities in the higher education curriculum. College Student Journal, 35(3). Retrieved from http://findarticles.com/p/articles/ mi_m0FCR/is_3_35/ai_80744653/?tag=content;col1

Felder, R. M., \& Brent, R. (1996). Navigating the bumpy road to student-centered instruction. College Teaching, 44(2), 43-57.

Foundation Coalition. (2011, November 27). Introduction to active and cooperative learning. Retrieved November 27, 2011, from http://www.foundationcoalition.org/home/keycomponents/collaborative_learning.html.

George, D., \& Mallery, P. (2003). SPSS for Windows step by step: A simple guide and reference. 11.0 update (4th ed.). Boston, MA: Allyn \& Bacon.

Gosser, D. K., \& Roth V. (1998). The workshop chemistry project: Peer-led team learning. Journal of Chemical education, 75(2), 185 - 187. Hager, P., Sleet, R. P., Logan, P., \& Hooper, M. (2003). Technical critical thinking in undergraduate science courses. Science \& Education, 12(3), 303-313.

Heller, P., Keith, R., \& Anderson, S. (1992). Teaching problem solving through cooperative grouping, part 1: Group versus individual problem solving. American Journal of Physics, 60(7), 627-636.Jacobs, G. M., Power, M. P., \& Inn, L. W. (2002). The teacher's sourcebook for cooperative learning. Thousand Oaks, CA: Corwin Press, Inc.

Johnson, D. W., \& Johnson, R. T. (1989). Cooperation and competition: Theory and research. Edina, MN: Interaction Book Company. 
Johnson, D. W., \& Johnson, R. T. (1994). Learning together and alone: Cooperative, competitive, and individualistic learning. Needham Heights, MA: Allyn and Bacon.

Johnson, D. W., \& Johnson, R. T. (1998). Cooperative learning and social interdependence theory. Retrieved from http://www.co-operation.org/ pages/SIT.html

Johnson, D. W., \& Johnson, R. T. (2000). Cooperative learning methods: A meta-analysis. Retrieved from http://www.co-operation.org/pages/cl-methods.html

Johnson, D. W., Johnson, R. T., Holubec, E. J., \& Roy, P. (1984). Circles of learning: Cooperation in the classroom. Alexandria, VA: Association for Supervision and Curriculum Development.

Johnson, D. W., Johnson, R. T., \& Smith K. A. (1991a). Active learning cooperation in college classroom. Edina, MN: Interaction Book Company.

Johnson, D. W., Johnson, R. T., \& Smith K. A. (1991b). Cooperative learning: Increasing college faculty instructional productivity. ASHE-ERIC Higher Education Reports. Jossey-Bass.

Johnson, R. T., \& Johnson, D. W. (1988). Cooperative learning: Two heads learn better than one. Transforming Education, 18. Retrieved from http://www.context.org/ ICLIB/IC18/Johnson.htm

Lyon, D. C., \& Lagowski, J. J. (2008). Effectiveness of facilitating small-group learning in large lecture classes. Journal of Chemical Education, 85(11), 1571-1576. 
Madhu, M., Schaefer, F., \& Morlino, E. (2008). Promoting student learning through group problem solving in general chemistry recitations. Journal of Chemical Education, 85(11), $1577-1581$.

Murray, J. P., \& Murray, J. I. (1992). How do I lecture thee? College Teaching, (40)3, 109-113.

Pence, H. E. (1993). Combining cooperative learning and multimedia in general chemistry. Journal of Chemical Education, 113, 375-380.

Quitadmo, I. J., Brahler, C. J., Crouch, G. J. (2009). Peer-led team learning: A prospective method for increasing critical thinking in undergraduate science. Science Educator, 18(1), $29-39$.

Rehfeldt, R. A., Walker, B., Garcia, Y., Lovett, S., \& Filipak, S. (2010) A point contingency for homework submission in the graduate school classroom. Journal of Applied Behavior Analysis, 43(3), 499-502.

Richards-Babb, M. Drelick, J., Henry, Z., \& Roberston-Honecker, J. (2011). Online homework, help or hindrance: What students think and how they perform. Journal of College Science Teaching, (40)4, $70-82$.

Ryan, C. S., \& Hemmes, N. S. (2005). Effects of the contingency for homework on homework submission and quiz performance in a college course. Journal of Applied Behavior Analysis, 38(1), $79-88$.

Scott, E. L. (2011). Retention and reform: An evaluation of peer-led team learning. Journal of Chemical Education, 88(6), 703 - 707. 
Sharan, S., E Shachar, C. (1988). Language and learning in the cooperative classroom. New York, NY: Springer-Verlag.

Sheridan, J., Byrne, A. C., \& Quina, K. (1989). Collaborative learning: Notes from the field. College Teaching, 37(2), 49-53.

Slavin, R. E. (1982). Cooperative learning: Student teams. Washington, D.C.: National Education Association.

Slavin, R. E. (1983). Student team learning. Washington, D.C.: National Education Association.

Slavin, R. E. (1988). Cooperative learning and student achievement. Educational Leadership,

Smith, M. E., Hinckley, C. C., \& Volk, G. L. (1991). Cooperative learning in the undergraduate laboratory. Journal of Chemical Education, 68(5), 413-415.

Stockdale, S. L., \& Williams, R. L. (2004). Cooperative learning groups at the college level: Differential effects on high, average, and low exam performers. Journal of Behavioral Education, 13(1), 37-50. 


\title{
Appendix A: Chemistry 110 Group Homework Evaluation
}

\author{
Spring 2008 \\ C. Eugene Bennett Department of Chemistry \\ Chem 110 Group Homework Evaluation
}

Please evaluate the Chemistry 110 group homework assignments by completing this research survey by circling the appropriate answer or writing your answer in the space provided.

\section{GENERAL INFORMATION}

\begin{tabular}{|c|c|c|c|c|c|c|}
\hline \multicolumn{7}{|l|}{ Name } \\
\hline Race & $\begin{array}{l}\text { African } \\
\text { American }\end{array}$ & Asian & Caucasian & Hispanic & $\begin{array}{l}\text { Middle } \\
\text { Eastern }\end{array}$ & Other: \\
\hline Gender & \multicolumn{3}{|c|}{ Male } & \multicolumn{3}{|c|}{ Female } \\
\hline Age & 18 & 19 & 20 & 21 & 22 & Other: \\
\hline Undergraduate Level & Freshman & \multicolumn{2}{|c|}{ Sophomore } & lunior & enior & $\begin{array}{l}\text { Non- } \\
\text { traditional }\end{array}$ \\
\hline \multicolumn{7}{|l|}{$\begin{array}{l}\text { Major or Anticipated } \\
\text { Major }\end{array}$} \\
\hline \multicolumn{7}{|l|}{$\begin{array}{l}\text { Number of credit hours } \\
\text { that you have completed } \\
\text { so far in your college } \\
\text { career (not including this } \\
\text { semester) }\end{array}$} \\
\hline \multicolumn{7}{|l|}{$\begin{array}{l}\text { How many credit hours } \\
\text { were you enrolled in at } \\
\text { the beginning of this } \\
\text { semester? }\end{array}$} \\
\hline \multicolumn{7}{|l|}{$\begin{array}{l}\text { How many credit hours } \\
\text { are your enrolled in now? }\end{array}$} \\
\hline $\begin{array}{l}\text { Is this your first time } \\
\text { taking Chem } 110 ?\end{array}$ & \multicolumn{3}{|l|}{ Yes } & & \multicolumn{2}{|c|}{$\begin{array}{l}\text { If no, how many } \\
\text { times have you } \\
\text { taken Chem } 110 \\
\text { including this } \\
\text { semester? }\end{array}$} \\
\hline $\begin{array}{l}\text { What grade do you think } \\
\text { you will earn in Chem } 110 \\
\text { this semester? }\end{array}$ & A & & & C & D & $\mathrm{F}$ \\
\hline $\begin{array}{l}\text { Are you enrolled in EDP } \\
101 \text { this semester? }\end{array}$ & \multicolumn{3}{|c|}{ Yes } & \multicolumn{3}{|c|}{ No } \\
\hline $\begin{array}{l}\text { Have you taken EDP } 101 \text { in } \\
\text { the past? }\end{array}$ & \multicolumn{3}{|c|}{ Yes } & \multicolumn{3}{|c|}{ No } \\
\hline
\end{tabular}




\section{GROUP FUNCTIONING}

\begin{tabular}{|c|c|c|c|}
\hline \multirow{2}{*}{$\begin{array}{l}\text { 1. How many times } \\
\text { did your group } \\
\text { meet this } \\
\text { semester? }\end{array}$} & $0-3$ & $4-7$ & $8-11$ \\
\hline & $12-15$ & $16-19$ & 20 or more times \\
\hline
\end{tabular}

2. Did you read your Cooperative Learning Workbook?

\begin{tabular}{|l|l|}
\hline Yes & No \\
\hline
\end{tabular}

3. Please circle the number that indicates the extent to which your group reviewed and revised the homework assignment before submitting it each week.

\begin{tabular}{|c|c|c|c|}
\hline 1 & 2 & 3 & 4 \\
\hline $\begin{array}{c}\text { My group never } \\
\text { reviewed and revised } \\
\text { our work }\end{array}$ & $\begin{array}{c}\text { My group occasionally } \\
\text { reviewed and revised } \\
\text { our work }\end{array}$ & $\begin{array}{c}\text { My group reviewed and } \\
\text { revised our work most of } \\
\text { the time }\end{array}$ & $\begin{array}{c}\text { My group always } \\
\text { reviewed and revised } \\
\text { our work }\end{array}$ \\
\hline
\end{tabular}

4. Please circle the number that indicates the extent to which your group assigned roles each week. (e.g., Group Leader, Task Manager, Student, or Teacher)

\begin{tabular}{|c|c|c|c|}
\hline 1 & 2 & 3 & 4 \\
\hline $\begin{array}{c}\text { My group did not assign } \\
\text { roles }\end{array}$ & $\begin{array}{c}\text { My group occasionally } \\
\text { assigned roles }\end{array}$ & $\begin{array}{c}\text { My group assigned roles } \\
\text { most of the time }\end{array}$ & $\begin{array}{c}\text { My group always } \\
\text { assigned roles }\end{array}$ \\
\hline
\end{tabular}

5. Please circle the number that indicates the extent to which your group alternated roles each week. (e.g., Group Leader, Task Manager, Student, or Teacher)

\begin{tabular}{|c|c|c|c|}
\hline 1 & 2 & 3 & 4 \\
\hline $\begin{array}{c}\text { My group did not } \\
\text { alternate roles }\end{array}$ & $\begin{array}{c}\text { My group occasionally } \\
\text { alternated roles }\end{array}$ & $\begin{array}{c}\text { My group alternated } \\
\text { roles most of the time }\end{array}$ & $\begin{array}{c}\text { My group always } \\
\text { alternated roles }\end{array}$ \\
\hline
\end{tabular}




\section{GROUP FUNCTIONING (CONTINUED)}

6. Please circle the number that indicates the extent to which your group processed group functioning each week.

\begin{tabular}{|c|c|c|c|}
\hline 1 & 2 & 3 & 4 \\
\hline $\begin{array}{c}\text { My group never } \\
\text { processed how we } \\
\text { functioned }\end{array}$ & $\begin{array}{c}\text { My group occasionally } \\
\text { processed how we } \\
\text { functioned }\end{array}$ & $\begin{array}{c}\text { My group processed } \\
\text { how we functioned most } \\
\text { of the time }\end{array}$ & $\begin{array}{c}\text { My group always } \\
\text { processed how we } \\
\text { functioned }\end{array}$ \\
\hline
\end{tabular}

\section{GROUP HOMEWORK COMPLETION}

7. Please circle the number that indicates the likelihood that you would have completed the work individually if you did not belong to a group.

\begin{tabular}{|c|c|c|c|}
\hline 1 & 2 & 3 & 4 \\
\hline $\begin{array}{c}\text { I would not have } \\
\text { completed the } \\
\begin{array}{c}\text { homework if required } \\
\text { individually }\end{array}\end{array}$ & $\begin{array}{c}\text { I would have } \\
\text { occasionally completed } \\
\text { the homework if } \\
\text { required individually }\end{array}$ & $\begin{array}{c}\text { I would have completed } \\
\text { the homework most of } \\
\text { the time if required } \\
\text { individually }\end{array}$ & $\begin{array}{c}\text { I would have completed } \\
\text { all of my homework } \\
\text { assignments if required } \\
\text { individually }\end{array}$ \\
\hline
\end{tabular}

8. Please circle the number that indicates the likelihood that you would have completed the group homework if not graded.

\begin{tabular}{|c|c|c|c|}
\hline 1 & 2 & 3 & 4 \\
\hline $\begin{array}{c}\text { I would not have } \\
\text { completed the group } \\
\text { homework if not graded }\end{array}$ & $\begin{array}{c}\text { I would have completed } \\
\text { some of the group } \\
\text { homework if not graded }\end{array}$ & $\begin{array}{c}\text { I would have completed } \\
\text { most of the group } \\
\text { homework even if not } \\
\text { graded }\end{array}$ & $\begin{array}{c}\text { I would have completed } \\
\text { all of the group } \\
\text { homework even if not } \\
\text { graded }\end{array}$ \\
\hline
\end{tabular}

9. The group homework assignments were worth 100 points of your final grade. Please circle the number that indicates the extent that you personally feel this was high enough to make you complete the group homework on a weekly basis.

\begin{tabular}{|c|c|c|}
\hline 1 & 2 & 3 \\
\hline 100 points were not high enough & $\begin{array}{c}100 \text { points were somewhat high } \\
\text { enough }\end{array}$ & 100 points were high enough \\
\hline
\end{tabular}




\section{GROUP HOMEWORK COMPLETION (CONTINUED)}

10. Please circle the number that indicates how often your group completed homework problems other than those assigned (for additional practice).

\begin{tabular}{|c|c|c|c|c|}
\hline 1 & 2 & 3 & 4 & 5 \\
\hline $\begin{array}{c}\text { My group never } \\
\text { completed } \\
\text { homework } \\
\text { problems other } \\
\text { than those } \\
\text { assigned }\end{array}$ & $\begin{array}{c}\text { My group } \\
\text { completed } \\
\text { homework } \\
\text { problems other } \\
\text { than those } \\
\text { assigned about } 3 \\
\text { out of the 10 } \\
\text { assignments }\end{array}$ & $\begin{array}{c}\text { My group } \\
\text { completed } \\
\text { homework } \\
\text { problems other } \\
\text { than those } \\
\text { assigned about } 5 \\
\text { out of the 10 } \\
\text { assignments }\end{array}$ & $\begin{array}{c}\text { My group } \\
\text { completed } \\
\text { homework } \\
\text { problems other } \\
\text { than those } \\
\text { assigned about 7 } \\
\text { out of the 10 } \\
\text { assignments }\end{array}$ & $\begin{array}{c}\text { My group } \\
\text { completed } \\
\text { homework } \\
\text { problems other } \\
\text { than those } \\
\text { assigned for all 10 } \\
\text { assignments }\end{array}$ \\
\hline
\end{tabular}

11. Please circle the number that indicates how often YOU completed homework problems other than those assigned (for additional practice).

\begin{tabular}{|c|c|c|c|c|}
\hline 1 & 2 & 3 & 4 & 5 \\
\hline $\begin{array}{c}\text { I never completed } \\
\text { homework } \\
\text { problems other } \\
\text { than those } \\
\text { assigned }\end{array}$ & $\begin{array}{c}\text { I completed } \\
\text { homework } \\
\text { problems other } \\
\text { than those } \\
\text { assigned about 3 } \\
\text { out of the 10 } \\
\text { assignments }\end{array}$ & $\begin{array}{c}\text { I completed } \\
\text { homework } \\
\text { problems other } \\
\text { than those } \\
\text { assigned about } 5 \\
\text { out of the 10 } \\
\text { assignments }\end{array}$ & $\begin{array}{c}\text { I completed } \\
\text { homework } \\
\text { problems other } \\
\text { than those } \\
\text { assigned about 7 } \\
\text { out of the 10 } \\
\text { assignments }\end{array}$ & $\begin{array}{c}\text { I completed } \\
\text { homework } \\
\text { problems other } \\
\text { than those } \\
\text { assigned for all 10 } \\
\text { assignments }\end{array}$ \\
\hline
\end{tabular}

12. Please circle the number that indicates the number of homework assignments that your group completed as a group.

\begin{tabular}{|c|c|c|c|c|}
\hline 1 & 2 & 3 & 4 & 5 \\
\hline $\begin{array}{c}\text { My group did not } \\
\text { completed any } \\
\text { homework } \\
\text { assignments }\end{array}$ & $\begin{array}{c}\text { My group } \\
\text { completed 3 or 4 } \\
\text { assignments }\end{array}$ & $\begin{array}{c}\text { My group } \\
\text { completed 5 or 6 } \\
\text { assignments }\end{array}$ & $\begin{array}{c}\text { My group } \\
\text { completed 7, 8, or } \\
9 \text { assignments }\end{array}$ & $\begin{array}{c}\text { My group } \\
\text { completed all 10 } \\
\text { homework } \\
\text { assignments }\end{array}$ \\
\hline
\end{tabular}




\section{GROUP HOMEWORK COMPLETION (CONTINUED)}

13. Please circle the number that most accurately describes your participation.

\begin{tabular}{|c|c|c|c|c|}
\hline 1 & 2 & 3 & 4 & 5 \\
\hline $\begin{array}{c}\text { I did not participate } \\
\text { in the group work }\end{array}$ & $\begin{array}{c}\text { I participated in the } \\
\text { group work for 3 } \\
\text { or 4 assignments }\end{array}$ & $\begin{array}{c}\text { I participated in the } \\
\text { group work for 5 } \\
\text { or 6 assignments }\end{array}$ & $\begin{array}{c}\text { I participated in the } \\
\text { group work for 7, } \\
8, \text { or 9 } \\
\text { assignments }\end{array}$ & $\begin{array}{c}\text { I participated in the } \\
\text { group work for all } \\
10 \text { assignments }\end{array}$ \\
\hline
\end{tabular}

14. Please circle the number indicates how often you rated your peers using the rating scale.

\begin{tabular}{|c|c|c|c|c|}
\hline 1 & 2 & 3 & 4 & 5 \\
\hline $\begin{array}{c}\text { I never rated my } \\
\text { group members }\end{array}$ & $\begin{array}{c}\text { I rated my group } \\
\text { members for 3 or 4 } \\
\text { assignments }\end{array}$ & $\begin{array}{c}\text { I rated my group } \\
\text { members for 5 or 6 } \\
\text { assignments }\end{array}$ & $\begin{array}{c}\text { I rated my group } \\
\text { members for 7, 8, } \\
\text { or 9 assignments }\end{array}$ & $\begin{array}{c}\text { I rated my group } \\
\text { members for all 10 } \\
\text { assignments }\end{array}$ \\
\hline
\end{tabular}

15. Did you meet with your group to complete homework set 13 ?

\section{Yes}

No

\section{GROUP HOMEWORK ATTITUDE}

16. Please circle the number that accurately describes the benefits you experienced from working in groups.

\begin{tabular}{|c|c|c|c|}
\hline 1 & 2 & 3 & 4 \\
\hline $\begin{array}{c}\text { I did not experience any } \\
\text { benefits from working in } \\
\text { groups }\end{array}$ & $\begin{array}{c}\text { I experienced very little } \\
\text { benefits from working in } \\
\text { groups }\end{array}$ & $\begin{array}{c}\text { I experienced some } \\
\text { benefits from working in } \\
\text { groups }\end{array}$ & $\begin{array}{c}\text { I experienced a lot of } \\
\text { benefits from working in } \\
\text { groups }\end{array}$ \\
\hline
\end{tabular}

17. Please circle the number that indicates the extent to which you think the group homework was worth the effort.

\begin{tabular}{|c|c|c|c|}
\hline 1 & 2 & 3 & 4 \\
\hline $\begin{array}{c}\text { It was not worth the } \\
\text { effort at all }\end{array}$ & $\begin{array}{c}\text { It was somewhat not } \\
\text { worth the effort }\end{array}$ & It was worth the effort & $\begin{array}{c}\text { It was well worth the } \\
\text { effort }\end{array}$ \\
\hline
\end{tabular}




\section{GROUP HOMEWORK ATTITUDE (CONTINUED)}

18. Please circle the number that accurately describes how you feel about group work.

\begin{tabular}{|c|c|c|c|}
\hline 1 & 2 & 3 & 4 \\
\hline $\begin{array}{c}\text { I strongly dislike group } \\
\text { work }\end{array}$ & $\begin{array}{c}\text { I somewhat dislike } \\
\text { group work }\end{array}$ & I like group work & I like group work a lot \\
\hline
\end{tabular}

19. Please indicate whether you will be more apt than before to take a course which includes group homework.

\begin{tabular}{|c|c|c|c|}
\hline 1 & 2 & 3 & 4 \\
\hline Unlikely & Somewhat Unlikely & Likely & Very Likely \\
\hline
\end{tabular}

20. Please circle the number that accurately describes how you think the group work impacted your grade in Chem 110

\begin{tabular}{|c|c|c|c|c|}
\hline 1 & 2 & 3 & 4 & 5 \\
\hline $\begin{array}{c}\text { Group work } \\
\text { significantly hurt } \\
\text { my grade in Chem } \\
110\end{array}$ & $\begin{array}{c}\text { Group work hurt } \\
\text { my grade in Chem }\end{array}$ & $\begin{array}{c}\text { Group work neither } \\
\text { hurt nor helped my } \\
\text { grade in Chem110 }\end{array}$ & $\begin{array}{c}\text { Group work helped } \\
\text { my grade in Chem } \\
110\end{array}$ & $\begin{array}{c}\text { Group work } \\
\text { significantly helped } \\
\text { my grade in Chem } \\
110\end{array}$ \\
\hline
\end{tabular}

21. Please circle the number that accurately describes how you feel about Chemistry.

\begin{tabular}{|c|c|c|c|c|}
\hline 1 & 2 & 3 & 4 & 5 \\
\hline $\begin{array}{c}\text { I don't like } \\
\text { Chemistry at all }\end{array}$ & $\begin{array}{c}\text { I somewhat dislike } \\
\text { Chemistry }\end{array}$ & $\begin{array}{c}\text { I neither like nor } \\
\text { dislike Chemistry }\end{array}$ & I like Chemistry & $\begin{array}{c}\text { I like Chemistry a } \\
\text { lot }\end{array}$ \\
\hline
\end{tabular}




\section{OPEN ENDED QUESTIONS}

Please write responses to the following questions:

22. Please indicate specific things that you like about working in groups.

23. Please indicate specific things that you didn't like about working in groups.

24. How would you change the group work in Chem 110 ?

25. How did you feel about rating your peers each week using the rating scales?

26. Please list any additional comments that you would like to make regarding your experience with cooperative learning. 


\section{Appendix B: Chemistry 110 Syllabus}

\section{CHEMISTRY 110: INTRODUCTION TO CHEMISTRY}

Spring 2008 SECTION: 002 CRN \#: 10967

Instructor: Mr. Mark Schraf

Office \#: 293-3435, Ext. 6413

E-Mail: mschraf@wvu.edu

Office and Hours: Clark 404 C M-F (12:45 p.m. - 1:30 p.m.); Tues, Thurs (9:30 a.m. - 9:45 a.m.)

You do not have to make an appointment to see me during the times listed above. Other times are available by appointment. PLEASE DO SO!!!!

Lecture: Section 001 M, W, F (10:30 a.m. - 11:20 a.m.) Clark Hall, Room 104

Text: Prep Chem by John Strohl

Note: Please turn off all cell phones before entering the classroom.

\section{Course Content}

Chem 110 covers chemical problem solving. Our purpose is to prepare students for the types of problems encountered in Chem 115 and 116. Some areas are covered in greater detail than in Chem 115 and 116 since the course deals specifically with chemical problem solving. The course is a two-hour credit and does not include much memorization of definitions and facts which will be covered in Chem 115 and 116. If you do not plan to take Chem 115, see me. I would like to discuss your reasons for taking Chem 110 to make sure you are doing the right thing.

\section{Calculators}

Calculators are necessary for Chem 110, 115 and 116 . Only non-programmable calculators may be used during quizzes and examinations in Chem 110, 115, and 116. If you plan to purchase one, a scientific calculator will provide the most help. The calculator you purchase should have at least the following advanced features (or their equivalent): EXP (or EE), yx (or xy), x/y (or y/x), log, ln, sin, cos, tan, STO, RCL and parentheses. Make sure you learn how to use your calculator properly (ie: read the directions accompanying your calculator). If you do not know how to use a certain function on your calculator ask a neighbor or ask me after class.

\section{Examination System}

All quizzes contain two parts: Competency (required) questions and Mastery (achievement) questions. Competency questions are the basic information you should be able to learn and are graded pass/fail. Mastery questions are worth ten points apiece with no partial credit and can move your grade to an A, B, or C.

There are 11 sets of competency questions; one set on each of the quizzes 1-5 and 7-12. ALL COMPETENCY QUESTIONS must be passed in order to pass the course (independent of the number of mastery points). If you fail any competency questions for a quiz, you must repeat the complete section of competency questions for that quiz (not just the specific problems you missed). You may take retests for the competency questions according to the schedule in the syllabus (you will have many chances for retakes) and will not be penalized as long as all competency questions are eventually passed within the following time frames: 
To avoid an " $F$ " at midterm, all competency questions for quizzes 1-5 must be passed by MONDAY, March 10, 2005. To avoid an "F" for the course, the competency questions for quizzes 1-5 must be passed by THURSDAY, March 20, 2008, and the competency questions for quizzes 712 must be passed by FRIDAY, May 2, 2008.

The reason for the competency questions is that Chem 110 is a preparation course so it is necessary to ensure that each student who completes Chem 110 can work the simplest problems in each area that will be necessary for Chem 115 and 116 . The retest system is designed so students can receive immediate feedback on the basic material they do not sufficiently understand in order to rectify the misunderstandings and apply the correct knowledge to the next chapter.

\section{Quizzes}

You will be given 10-30 minutes per quiz depending on the quiz difficulty. Graded quizzes will be returned the next class period. Save all of your quizzes. Your graded quizzes serve as proof of your grade. They also provide an excellent study tool for other examinations in this course.

NOTE: Possession or use of cell phones, text messengers, or any other communication device during a quiz will result in a zero for that quiz and possible academic fraud charges being brought against those violating this policy.

\section{Retests}

Retest I consists of competency question sets from Quizzes 1-5 while Retest II consists of competency question sets from Quizzes 7-12. Retests are administered every Monday during the last 5-10 minutes of class. You should use the retests to get ahead on your competency questions or to catch up if you are behind.

\section{Homework Group Assignments}

All students will be required to participate in ten group homework assignments (10 points each, for a total of 100 homework points) that will be completed outside of class. These homework assignments are in addition to the individual homework assignments outlined in this syllabus (which will NOT be collected or graded, but will be similar to the group homework as well as VERY IMPORTANT FOR UNDERSTANDING THE CLASS MATERIAL). The groups will be assembled by the instructor, and details regarding this portion of the course will be provided in the coming weeks.

\section{Attendance Policy}

Attendance will contribute to each student's final grade as shown below. Nonattendance at lecture is considered an absence whether it is excused or unexcused.

3 absences or less: 10 mastery points will be added to the final numerical grade.

5-9 Absences: Grade will be dropped by one letter grade.

10-14 Absences: Grade will be dropped by two letter grades.

15-19 Absences: Grade will be dropped by three letter grades.

$>20$ Absences: Student will receive an "F" grade.

\section{Absence from a Quiz}

If you are ill and contact me as soon as possible by phone or e-mail, you may make up the quiz during office hours. If you need to go out of town on University business, you must submit a note in advance listing your time of departure and return. Missed quizzes must be made up within a week of the actual date of the missed quiz. Other cases will be dealt with on an individual basis. 
West Virginia University is committed to social justice. I concur with that commitment and expect to foster a nurturing learning environment based upon open communication, mutual respect, and nondiscrimination. Our University does not discriminate on the basis of race, sex, age, disability, veteran status, religion, sexual orientation, color or national origin. Any suggestions as to how to further such a positive and open environment in this class will be appreciated and given serious consideration. If you are a person with a disability and anticipate needing any type of accommodation in order to participate in this class, please advise me and make appropriate arrangements with Disability Services (293-6700).

\section{HOW CHEM 110 WORKS}

Chem 110 is designed to improve the problem solving and math abilities of students to the point that they will be able to succeed in Chem 115 and 116. Previous knowledge of chemistry is NOT required: in fact, the course was designed to help this type of student prepare to continue in college chemistry. A grade of " $C$ " or better in Chem 110 is an indication that a student should be able to handle the material in Chem 115 and 116.

The course is relatively easy for students who keep up with the syllabus, work sufficient number of exercises and get their questions answered during the class or office hours. The course is exceedingly difficult for students who study only the night before a quiz, etc. Most of the students who drop do so because they get behind. In addition to learning chemical problem solving, it is necessary to organize your study time and develop an approach to the course that will work for you. I can help you with these areas during my office hours. Chem 110 testing using Competency and Mastery questions is designed to help students keep up with the course material, aid students in identifying specific weaknesses and provide opportunities to eliminate them, as well as remind students to maintain a steady pace of study throughout the semester.

Competency questions include the basic, fundamental concepts of a chapter, and these skills will be utilized throughout the semester for all types of problems, so it is imperative that students develop expertise with these questions. Students who do not rectify their deficiencies with competency questions immediately will struggle to succeed in all subsequent chapters. If a student cannot completely understand and implement the information contained in the competency questions throughout the rest of the semester, this is a clear indication that the student is not ready to enroll in Chem 115.

Bottom line, to pass Chem 110, you must have a really good understanding of the basic concepts included in ALL 11 sets of competencies. If you understand how to balance chemical equations (Competency 5) but cannot use molar mass for conversions (Competency 4), then you have not met the objectives of Chem 110 and are not ready for Chem 115. You must pass all 11 Competencies on Quizzes 1-5 and 7-12 in order to pass Chem 110.

Mastery questions will test students at a higher level, often combining two or more competency level questions, and often require students to use problem solving skills. These questions determine a student's true understanding of all the material in a particular section, and of the course as a whole.

Bottom line, to get a grade of $\mathrm{A}, \mathrm{B}$, or $\mathrm{C}$ in Chem 110, in addition to understanding and applying the basic concepts included in ALL 11 sets of competencies. You must be able to complete multi-step problems, word problems, and other more complex questions. However, these concepts are only the basic information that is required in Chem 115, so if you do not attempt this more difficult material in Chem 110, you will not be ready for Chem 115. Many students become frustrated with the fact that partial credit is not given in Chem 110. However, unlike a term paper or an essay question, science problems, especially those involving mathematical equations, have a single, distinct, and exact solution. There 
is only one correct answer, and part of the job of Chem 110 is to prepare students to recognize this fact. Science is also extremely detail-oriented (a little mistake can result in a big problem), so Chem 110 is also designed to teach students that every number they write must have the proper significant figures, units, and rounding, or it will be marked as incorrect. This concept is no less important than any other in the class, and will be continually reinforced throughout the semester. SO BE READY FOR IT! The following chart will help you understand the individual skills that will be required in order to perform well on both sections of each quiz this semester. REMEMBER, THESE ARE NOT ISOLATED TOPICS TO BE MEMORIZED AND THEN IGNORED! THE INFORMATION YOU LEARN IN THE COMPETENCY SECTION OF QUIZ \#1 WILL STILL APPLY IN THE MASTERY SECTION OF QUIZ \#12, for example. So it is vitally important that you learn and retain the material throughout the course, and also that you use your graded quizzes to discover the concepts you do not understand, correct the deficiencies, and then practice the homework problems that apply in order to master this material.

\section{CHEM 110 CUMULATIVE WEEKLY CONCEPTUAL GOALS}

\begin{tabular}{|c|c|c|}
\hline By Quiz __, you can... & Competency & Mastery \\
\hline 1 & $\begin{array}{l}\text { perform math operations on measured } \\
\text { numbers using significant } \\
\text { figure rules; convert numbers into standard } \\
\text { scientific notation; } \\
\text { mass percentage calculation }\end{array}$ & $\begin{array}{l}\text { algebraic manipulation; mixed operation } \\
\text { calculations with significant figures; mass \% } \\
\text { calc.; + or - exponential numbers }\end{array}$ \\
\hline 2 & $\begin{array}{l}\text { metric to metric conversion; temp conv.; } \\
\text { metric to English } \\
\text { conversion; use of dimensional analysis }\end{array}$ & $\begin{array}{l}\text { multi-step conversions; complex unit } \\
\text { conversion; } \mathrm{K} \text { to /F conversion }\end{array}$ \\
\hline 3 & $\begin{array}{l}\text { subatomic particles in atoms; atoms, ions, } \\
\text { outer shell electrons, } \\
\text { formula unit }\end{array}$ & $\begin{array}{l}\text { ions from formula unit, subatomic particles } \\
\text { in ions, \# of electrons in ions; formula unit } \\
\text { from } \\
\text { ions; bond type ID }\end{array}$ \\
\hline 4 & $\begin{array}{l}\text { mole conversions/ } \mathrm{N}_{\mathrm{A}} \text {; molar mass } \\
\text { conversions }\end{array}$ & $\begin{array}{l}\text { density conversion; STP gas conversions; } \\
\text { molarity and concentration }\end{array}$ \\
\hline 5 & balance chem equation; mole stoichiometry & balance eqn; limiting reagent stoich. \\
\hline 6 (Midterm) & $\begin{array}{l}\text { No competency questions on midterm, but } \\
\text { must be proficient with } \\
\text { all concepts from Quizzes 1-5 }\end{array}$ & $\begin{array}{l}\text { All Quiz 1-5 material, plus mass \% of } \\
\text { elements } \\
\text { in compounds; empirical formula; mass } \\
\text { stoichiometry and lim reagents; gen rxn } \\
\text { probs }\end{array}$ \\
\hline 7 & net ionic eqn.; ID acid/base in rxn & $\begin{array}{l}\text { solub. rules, ID acid/base; net ionic eqn; } \\
\text { predict products }\end{array}$ \\
\hline 8 & $\begin{array}{l}\text { molarity of ions in soln; molarity/vol } \\
\text { conversion }\end{array}$ & $\begin{array}{l}\text { molarity of ions; dilution; lim reagents with } \\
\text { solutions; gen. rxn probs }\end{array}$ \\
\hline 9 & write equil const expression; calculate $\mathrm{K}$ & $\begin{array}{l}\text { equil const expression/calculations; gen } \\
\text { problems with multi-step rxns }\end{array}$ \\
\hline 10 & balance simple redox rxn; assign oxidation \# & $\begin{array}{l}\text { bal. simple redox rxn; assign oxidation \#; } \\
\text { balance acidic redox rxn; gen rxn prob }\end{array}$ \\
\hline 11 & $\begin{array}{l}\text { assign oxid/red agent; ideal gas law; non- } \\
\text { static gas law calc. }\end{array}$ & $\begin{array}{l}\text { balance redox in acid/base; static gas law } \\
\text { calc. }\end{array}$ \\
\hline 12 & simple heat eqn calculation & $\begin{array}{l}\text { heat eqn calculation; heat of phase change } \\
\text { calc.; heat lost/gained; gas density }\end{array}$ \\
\hline 13 & No competency questions. & $\begin{array}{l}\text { phase change heat calc.; gen heat rxn prob; } \\
\text { balance nuclear rxn; mass/energy nuclear rxn } \\
\text { conv.; radioactive decay }\end{array}$ \\
\hline Final & $\begin{array}{l}\text { No competency questions on final exam, but } \\
\text { must be proficient } \\
\text { with all concepts from Quizzes } 1-5 \text { and } 7-12\end{array}$ & $\begin{array}{l}\text { All Quiz 1-13 material, plus Lewis structures } \\
\text { and shapes of molecules }\end{array}$ \\
\hline
\end{tabular}




\section{CHEM 110 Course Performance and Grading}

Chem 110 is designed to improve math and problem solving skills to the point expected for success in Chem 115 and 116. A grade of A or B usually indicates that students' study habits and problem solving skills are sufficiently good that they won't have difficulty with the material in Chem 115 and Chem 116 as long as they continue to study regularly, etc. A grade of $C$ indicates that there will be some areas of difficulty so the student should expect to spend extra time and effort in Chem 115. Five quizzes and midterm exam will be used for the computation of the mid-term grade. The mastery points on these tests are 50, 50, 50, 40, 30 and 120 for a total of 340 mastery points at mid-term.

The mid-term grade scale is:

A $=$ 280-340 Mastery Points (Assuming all competency questions 1-5 passed)

$\mathrm{B}=230-270$ Mastery Points (Assuming all competency questions 1-5 passed)

$\mathrm{C}=170-220$ Mastery Points (Assuming all competency questions 1-5 passed)

$\mathrm{D}=0$-170 Mastery Points (Assuming all competency questions 1-5 passed)

$\mathrm{F}=$ All competency questions 1-5 not passed (regardless of \# of Mastery points).

The thirteen quizzes, homework score (100 points for ten homework assignments), and final exam will be used for the computation of the final grade. The mastery points on quizzes 7-13 as well as the final exam are $40,50,40,40,40,50,60$, and 240 . The total number of points possible in the course is 1000 including the 240 points for the final exam. The final grade scale is:

A $=700-1000$ Total points (Assuming all competency questions 1-5, 7-12 passed)

$\mathrm{B}=570-695$ Total points (Assuming all competency questions 1-5, 7-12 passed)

$\mathrm{C}=410-565$ Total points (Assuming all competency questions 1-5, 7-12 passed)

$\mathrm{D}=0$ - 405 Total points (Assuming all competency questions 1-5, 7-12 passed)

$\mathrm{F}=$ All competency questions 1-5, 7-12 not passed (regardless of number of total points)

\section{CHEM 110 WEEKLY PROGRESS}

\begin{tabular}{|c|c|c|c|c|c|}
\hline Quiz & $\begin{array}{l}\text { Comp } \\
\text { (Pass/ } \\
\text { Fail) }\end{array}$ & $\begin{array}{l}\text { Mastery } \\
\text { (out of } \\
\text { points) }\end{array}$ & Quiz & $\begin{array}{l}\text { Comp } \\
\text { (Pass/Fail) }\end{array}$ & $\begin{array}{l}\text { Mastery } \\
\text { (out of ___ points) }\end{array}$ \\
\hline 1 & & out of $50 \mathrm{pts}$ & 7 & & out of 40 pts \\
\hline 2 & & out of $50 \mathrm{pts}$ & 8 & & out of $50 \mathrm{pts}$ \\
\hline 3 & & out of $50 \mathrm{pts}$ & 9 & & out of $40 \mathrm{pts}$ \\
\hline 4 & & out of $40 \mathrm{pts}$ & 10 & & out of $40 \mathrm{pts}$ \\
\hline 5 & & out of $30 \mathrm{pts}$ & 11 & & out of 40 pts \\
\hline \multirow[t]{5}{*}{6 (midterm) } & None & out of $120 \mathrm{pts}$ & 12 & & out of $50 \mathrm{pts}$ \\
\hline & & $\begin{array}{l}\text { out of } 340 \text { pts } \\
\text { Add quizzes } 1-6\end{array}$ & 13 & None & __ out of $60 \mathrm{pts}$ \\
\hline & & & Hmwk & None & out of $100 \mathrm{pts}$ \\
\hline & & & Final & None & out of $240 \mathrm{pts}$ \\
\hline & & & Total & & $\begin{array}{l}\text { out of } 1000 \text { pts } \\
\text { (add Quiz 1-13 + } \\
\text { hmwk) }\end{array}$ \\
\hline
\end{tabular}


CHEMISTRY 110- SPRING 2008 Section 002: M, W, F 10:30 AM - 11:20 AM

\begin{tabular}{|c|c|c|}
\hline Date & Chapter & Homework Sets \\
\hline M, $1 / 14$ & 1 & 1.A-1.E \\
\hline $\mathrm{W}, 1 / 16$ & 1 & $1 . \mathrm{F}-1 . \mathrm{K}$ \\
\hline $\mathrm{F}, 1 / 18$ & 1 & 1.L - 1.P \\
\hline $\mathrm{M}, 1 / 21$ & No Class & \\
\hline $\mathrm{W}, 1 / 23$ & Quiz \#1 on chapter 1 & 2.A-2.B \\
\hline $\mathrm{F}, 1 / 25$ & 2 & 2.C - 2.D \\
\hline M, $1 / 28$ & 2 & $2 . E-2 . F$ \\
\hline $\mathrm{W}, 1 / 30$ & Quiz \#2 on chapter 2 & 3.A-3.B \\
\hline $\mathrm{F}, 2 / 1$ & 3 & $3 . \mathrm{C}-3 . \mathrm{F}$ \\
\hline $\mathrm{M}, 2 / 4$ & 3 & $3 . G-3 . K$ \\
\hline $\mathrm{W}, 2 / 6$ & Quiz \#3 on chapter 3 & \\
\hline $\mathrm{F}, 2 / 8$ & 5 & Read chapter 4 / 5.A - 5.H \\
\hline M, 2/11 & 5,6, and 7 & 5.I; 6.A; 7.A - 7.B \\
\hline W, $2 / 13$ & Quiz \#4 on chapter 5 & \\
\hline $\mathrm{F}, 2 / 15$ & 7 & 7.C - 7.F \\
\hline M, 2/18 & 7 & 7.G-7.I \\
\hline $\mathrm{W}, 2 / 20$ & $\begin{array}{c}\text { Quiz \#5 } \\
\text { on exercise sets 7.A - 7.G }\end{array}$ & \\
\hline $\mathrm{F}, 2 / 22$ & 8 & 8.A-8.E \\
\hline M, 2/25 & Review & \\
\hline W, 2/27 & $\begin{array}{c}\text { Quiz } \\
\text { Midterm Exam on chapters } 1 \text { - } 8\end{array}$ & \\
\hline F, 2/29 & 9 & 9.A-9.B \\
\hline $\mathrm{M}, 3 / 3$ & 9 & 9.C-9.E \\
\hline $\mathrm{W}, 3 / 5$ & $\begin{array}{c}\text { Quiz \#7 on exercise sets 9.A - } \\
\text { 9.D }\end{array}$ & \\
\hline $\mathrm{F}, 3 / 7$ & 9 & $9 . \mathrm{F}-9 . \mathrm{H}$ \\
\hline $\mathrm{M}, 3 / 10$ & 10 & 10.A-10.C \\
\hline W, 3/12 & $\begin{array}{c}\text { Quiz \#8 on exercise sets 9.E - } \\
10 . B\end{array}$ & \\
\hline$F, 3 / 14$ & 10,11 & 10.D; 11.A-11.C \\
\hline M, 3/17 & 11 & 11.D - 11.G \\
\hline W, 3/19 & $\begin{array}{c}\text { Quiz \#9 on exercise sets } 10 . C- \\
\text { 11.G }\end{array}$ & \\
\hline F, 3/21 & No Class & \\
\hline $\mathrm{M}, 3 / 31$ & 12 & 12.A - 12.H \\
\hline $\mathrm{W}, 4 / 2$ & 12 & 12.I - 12.K \\
\hline $\mathrm{F}, 4 / 4$ & $\begin{array}{c}\text { Quiz \#10 on exercise sets } 12 . \mathrm{A}- \\
12 . \mathrm{H}\end{array}$ & \\
\hline M, 4/7 & 13,14 & 13.A-13.E \\
\hline $\mathrm{W}, 4 / 9$ & 14 & 14. $\mathrm{A}-14 . \mathrm{B}$ \\
\hline F, 4/11 & $\begin{array}{c}\text { Quiz \#11 on exercise sets } 12 . \mathrm{I}- \\
\text { 12.K; } 13 . \mathrm{A}-13 . \mathrm{D}\end{array}$ & \\
\hline M, 4/14 & 14 & 14.D - 14.E \\
\hline W, 4/16 & 14 & 14.F - 14.H \\
\hline
\end{tabular}




\begin{tabular}{|c|c|c|}
\hline F, 4/18 & $\begin{array}{c}\text { Quiz \#12 on exercise sets 13.E - } \\
\text { 14.E, excluding 14.C }\end{array}$ \\
\hline M, 4/21 & 15 & 14.C; 15.A - 15.C \\
\hline W, 4/23 & 15 & $15 . \mathrm{D}-15 . \mathrm{E}$ \\
\hline $\mathrm{F}, 4 / 25$ & $\begin{array}{c}\text { Quiz \#13 on exercise sets 14.C; } \\
14 . \mathrm{F}-15 . \mathrm{C}\end{array}$ \\
\hline $\mathrm{M}, 4 / 28$ & 17 & $17 . \mathrm{A}-17 . \mathrm{B}$ \\
\hline $\mathrm{W}, 4 / 30$ & 17 & $17 . \mathrm{C}-17 . \mathrm{D}$ \\
\hline $\mathrm{F}, 5 / 2$ & Review & \\
\hline & & \\
\hline
\end{tabular}

FINAL EXAM: TUESDAY, MAY 6, 2008 7:00-9:00 P.M. (LOCATION T.B.A.) 


\section{Appendix C: Chemistry 110 Group Homework Overview}

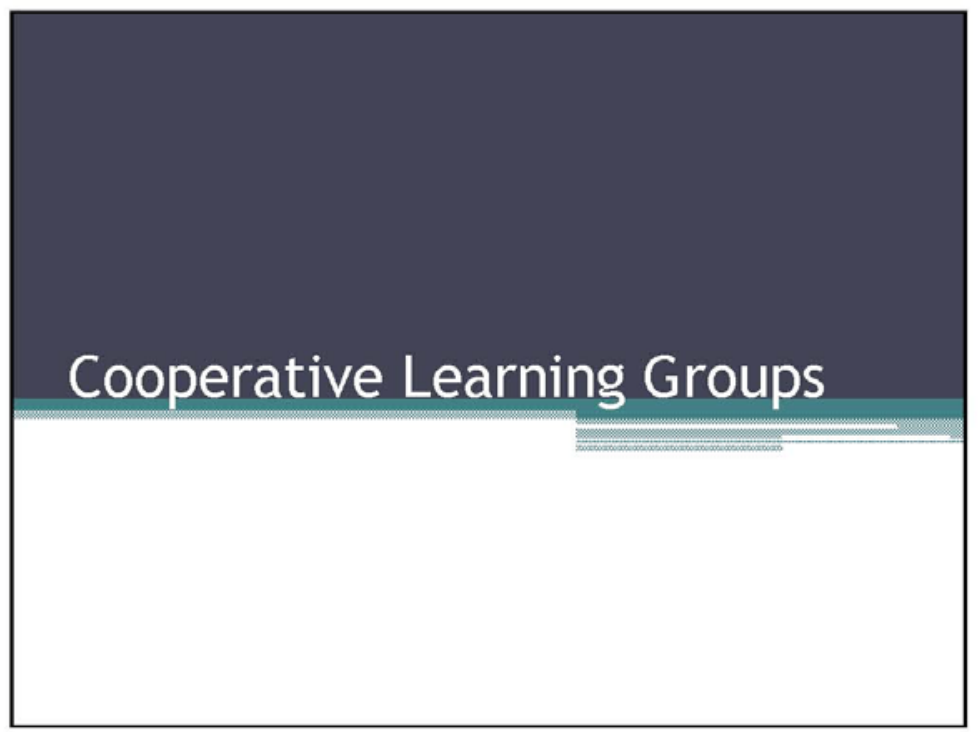

\section{Cooperative Learning Workbook}

- Contains more in depth information regarding Cooperative Learning Groups.

- Provides detailed information on the grading procedures.

- Provides detailed information on assigned roles and social skills.

- Use as a journal to reflect on weekly group meetings.

Follow along in your workbook during this presentation. 


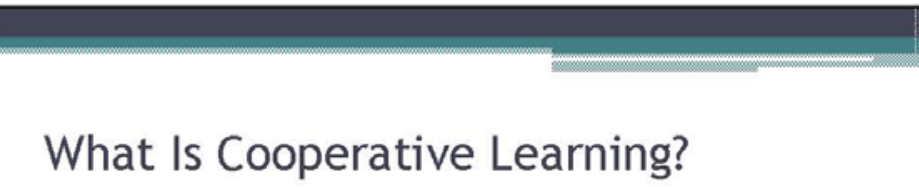

- You will be working in groups of about 6 to complete your homework assignments.

- Your groups will meet outside of class time.

- Much more than working in groups - members must work together to achieve a common goal.

- Your common goal is mastery of Chemistry 110 concepts.

\section{What Is Cooperative Learning?}

- To make sure your group time is beneficial, the group must

- Work through problems together.

- Engage in dialogue to discuss the steps involved in solving the problems.

- Resolve disagreements.

- Check you work and revise as necessary.

- Evaluate how the group is working together as a team. 


Your Group Assignment
- You will be placed into assigned groups.
- If you are in the MWF sections, you will be given
your group number in class on Friday, 2/1.
- If you are in the TR section, you will receive your
group number via email on Friday, 2/1.
- All emails will be sent to your MIX account.
- All sections will be given time during class to
exchange contact information and to schedule
your first meeting.

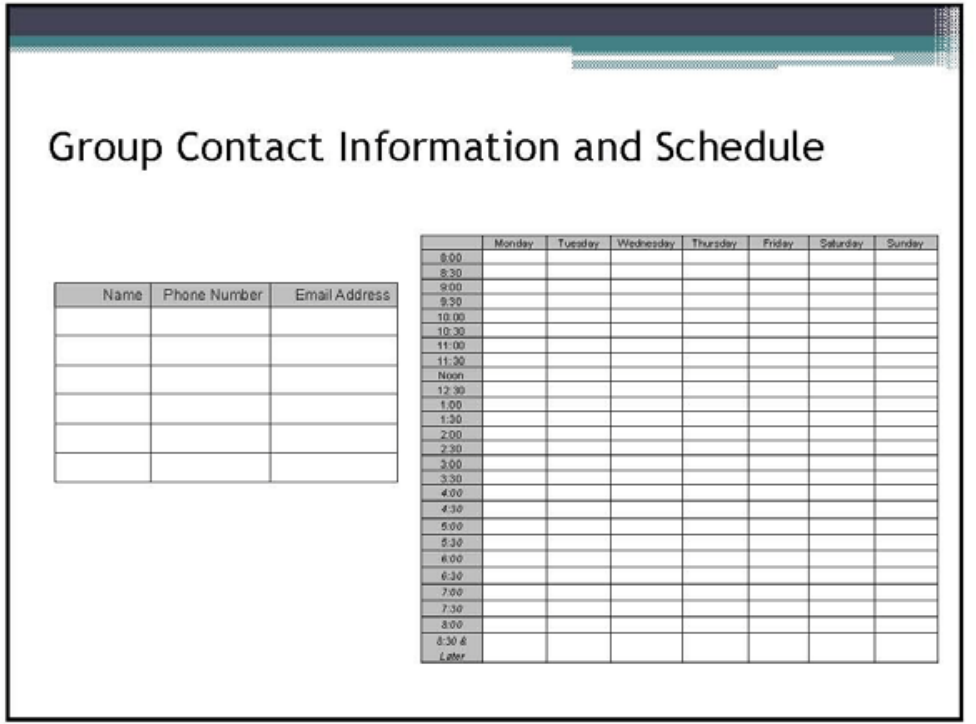




Steps:
1. Meet face-to-face each week.
2. Assign roles.
3. Show all work and answers.
4. Use a different color ink to grade your work.
5. Use a different color ink to make revisions.
6. Use active listening skills.
7. Process group functioning.

\begin{tabular}{l}
\hline Roles and Responsibilities \\
- Team Leader \\
- Recorder \\
- Teacher \\
- Student \\
- Task Manager \\
\multicolumn{2}{c|}{ Alternate Roles Each Week } \\
THE GROUP SHOULD ALWAYS BE A FUN AND \\
$\quad$ SAFE PLACE TO LEARN \\
\hline
\end{tabular}




Grading Procedures
- Your grade is determined by two factors:
1.Performance
$\quad$ The group will turn in one copy of the
homework.
Homework will be graded for accuracy and
returned.
Each assignment is worth 1o points.

Grading Procedures
1. Group Contribution
- You will be required to rate the individuals in your
group.
- You will use a 3-point scale
1 = Did Nolow Expectation
2 = At Expectation




\section{Grading Procedures}

- Each week you will email the ratings for each member in your group to your section's email address by 11:59 p.m. each Wednesday (MWF) or each Thursday (TR).

$\begin{array}{lll}\text { MWF } & \text { 9:30 } & \text { chem110sec1@yahoo.com } \\ \text { MWF } & \text { 10:30 } & \text { chem110sec2@yahoo.com } \\ \text { TR } & \text { 10:00 } & \text { chem11osec3@yahoo.com }\end{array}$

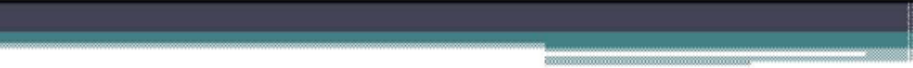

\section{Grading Procedures}

- Just as you will rate your peers, they will also rate you.

- Based on the rating score that you receive each week, the points earned on the Cooperative Learning assignment will either stay the same or decrease as follows:

Two or more ratings of a $0=0 / 10$

Two or more ratings of a $1=5 / 10$

Two or more ratings of a $2=10 / 10$ 


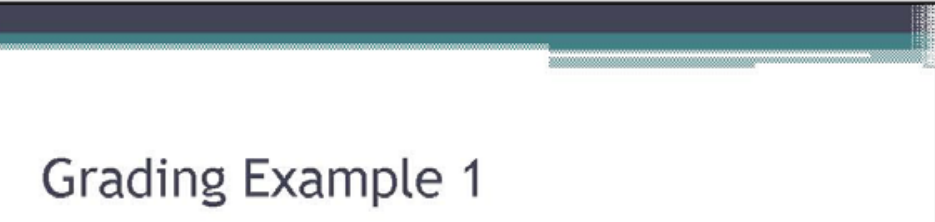

Your group turned in a Cooperative Learning assignment and received a perfect score 10/10.

-The members in your group submitted the following rating scores for your contribution:

- Group member 1 gave you a 1

- Group member 2 gave you a 2

- Group member 3 gave you a 1

- Group member 4 gave you a 2

- Group member 5 gave you a 2

-You earned two ratings of 1 and three ratings of 2 . Therefore, your overall score will stay a $10 / 10$ for this Cooperative Learning assignment.

Grading Example 2

Your group turned in a Cooperative Learning assignment and received a perfect score $10 / 10$.

-The members in your group submitted the following rating scores for your contribution:

- Group member 1 gave you a 2

Group member 2 gave you a 1

- Group member 3 gave you a 1

- Group member 4 gave you a 1

Group member 5 gave you a 2

-You earned two ratings of 2 and three ratings of 1 . Therefore, your overall score will be reduced by $50 \%$ and you will receive a $5 / 10$ for this Cooperative Learning assignment. 


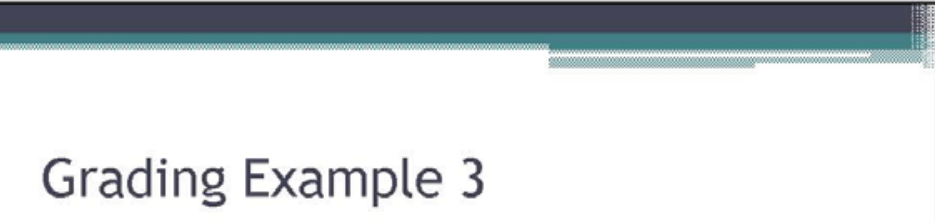

Your group turned in a Cooperative Learning assignment and received a perfect score 10/10.

-The members in your group submitted the following rating scores for your contribution:

- Group member 1 gave you a o

- Group member 2 gave you a 0

- Group member 3 gave you a o

- Group member 4 gave you a 1

- Group member 5 gave you a 1

-You earned two ratings of 1 and three ratings of o. Therefore, you will receive $\mathrm{a} 0 / 10$ for this Cooperative Learning assignment.

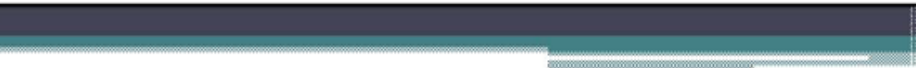

Grading Example 4

Your group turned in a Cooperative Learning assignment and received a perfect score $10 / 10$,

-The members in your group submitted the following rating scores for your contribution:

- Group member 1 gave you a o

Group member 2 gave you a 1

Group member 3 gave you a 1

- Group member 4 gave you a 2

- Group member 5 gave you a 2

-You earned one rating of o, two ratings of 1 and two ratings of 2. Therefore, you will receive a $10 / 10$ for this Cooperative Learning assignment.

- Majority will always rule when calculating the rating scores.

- Obviously, these ratings scores indicate something happened within the group because the members have a very different perspective on the same person's weekly contribution. 


\section{Grading (continued)}

- The rating scales will be kept confidential.

- It is essential that you rate the members in your group as fairly and accurately as possible.

\section{IMPORTANT NOTE:}

THE RATING SCALE IS NOT OPTIONAL. ANY STUDENT WHO DOES NOT SUBMIT A RATING SCORE FOR ALL MEMBERS OF HIS OR HER GROUP WILL RECEIVE A ZERO ON THE COOPERATIVE LEARNING ASSIGNMENT FOR THE WEEK.

Weekly Notes

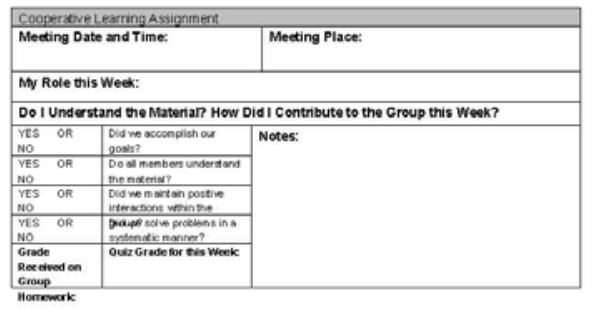




Social Skills
- Just as Cooperative Learning is linked to increased
performance, it is also associated with better use of
social skills.
Given the world we live in and the fact that most
work and educational settings involve other people,
it is important to practice social skills that help us
work together in meaningful ways.
- Communication
Active Listening
- Leadership
Decision-Making
Conflict Resolution


Appendix D: Cooperative Learning Workbook

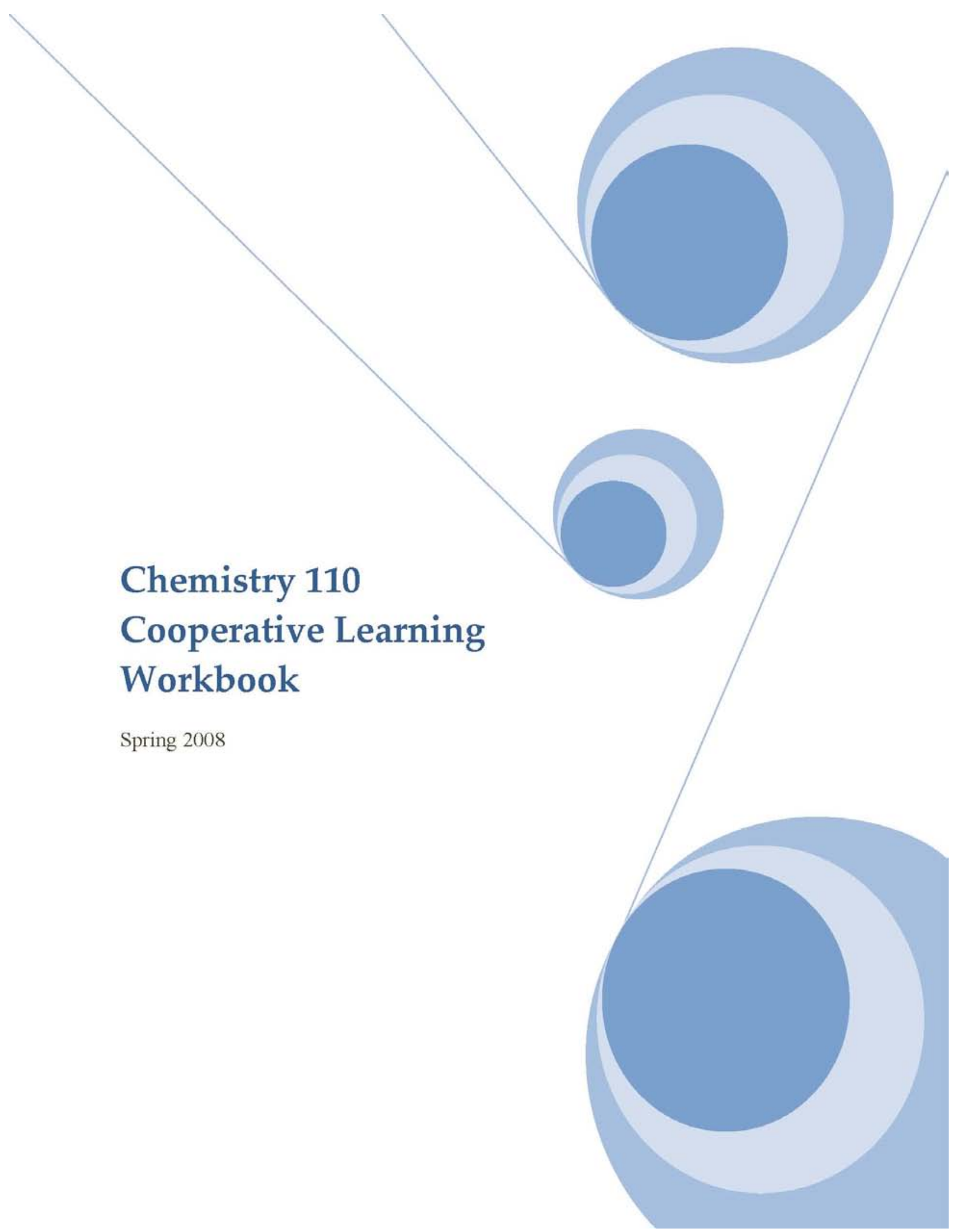




\section{TABLE OF CONTENTS}

What is Cooperative Learning

How Do You Run Effective Cooperative Learning Groups?

Roles and Responsibilities

Group Contact Information \& Schedule

How Will the Cooperative Learning Assignments Be Graded?

Weekly Notes

Social Skills Information Sheet
Page 3

Page 3

Page 4

Page 5

Pages 6-10

Pages $10-15$

Pages 16 - 17 


\section{What Is Cooperative Learning?}

You will be working in groups of about six to complete your Chemistry 110 homework problems. This project will set you up for success by providing you a structured way to learn and master the concepts taught in Chemistry 110. Your Cooperative Learning Groups will meet outside of class time to complete weekly assignments for the next 10 weeks.

Cooperative Learning is much more than just working in groups. It has been researched for over 30 years and has been proven to improve performance if done properly. That is, members must work together to achieve a common goal - mastery of the concepts. To make sure your time as a group is most beneficial, it is important that your group works through the problems together... actively problem solving, explaining steps to one another, resolving disagreements, checking one another's work, revising as a team, and last but not least discussing group functioning. There is a "sink or swim" philosophy within the groups. All members should make sure that every other member in the group understands how to do the homework assignments. If the group can not do this on their own, you must contact your instructor for assistance.

\section{How Do You Run Effective Cooperative Learning Groups?}

The benefits that you will experience from working in Cooperative Learning Groups are directly related to the effort you put into them. At a minimum the group should:

Meet face-to-face each week to work as a team to complete the assigned homework.

Assign roles and responsibilities each week. (See Roles and Responsibilities on Page 4.)

$\square$ Show all work and answers for each homework problem.

$\square$ Use a different color ink to grade your work after completing the problems.

$\square$ Show revisions if answers are incorrect using a different color ink.

$\square$ Make photocopies so that each member of the group has access to the exercise sets in preparation for the weekly Chemistry 110 quiz. (Before handing the homework assignment in for grading.)

$\square$ Use active listening skills as well as other social skills to work as a team. (See the Social Skills Information sheet on Page 15.)

$\square$ Process your group's functioning during the last five minutes of each meeting. Ask questions such as:

$\checkmark$ Did we accomplish our goals?

$\checkmark$ Do all members understand the material?

$\checkmark$ Did we maintain positive interactions within the group?

$\checkmark$ Did we solve problems in a systematic manner? 


\section{Roles and Responsibilities}

There are several roles that need to be fulfilled in your Cooperative Learning Groups: Team Leader, Recorder, Teacher, Student, and Task Manager.

- Team Leader:

- Manages the meeting schedule.

- Ensures that the assignment is complete.

- Turns in the actual assignment.

- Overall accountability person for the week.

- Recognizes when the team is not working well and brings it to everyone's attention in a mature and nonthreatening manner (along with Team Leader).

- Ensures that the group spends the last five minutes of each meeting discussing how the group is functioning in terms of efficiency and quality of work.

\section{- Recorder:}

- Writes / records while meeting as a group.

- Ensures the assignment shows all steps necessary to complete each problem and that different color inks are used to indicate revisions to the problems.

- Teacher:

- Is comfortable enough with the weekly topic to take the lead in explaining concepts as necessary.

- Attempts to answer student questions to the best of his or her ability.

- Recognizes when the group needs help from the instructor.

- Student:

- Is an active member of the group even though he or she may need extra help with the concepts?

- Asks questions for clarification.

- Explains where he or she is having difficulty.

- Task Manager:

- Keeps the group moving and on task.

- Informs the Team Leader if there are problems associated with completing the work.

- Recognizes when the team is not working well and brings it to everyone's attention in a mature and nonthreatening manner (along with the Team Leader).

Within your Cooperative Learning Groups, each member should take on a new role each week. It is understandable and expected that multiple members may be "students" and "teachers" at one time. For example, the Team Leader may also be a student or the teacher. No one member of the group is "in charge". To keep this from happening it is essential that there is always a Team Leader and a Task Manager who work together to ensure the group is accomplishing the common goal of concept mastery. THE GROUP SHOULD ALWAYS BE A SAFE AND FUN PLACE TO LEARN. 


\section{Group Contact Information \& Schedule}

Please complete this form with all the information you need to contact your fellow group members.

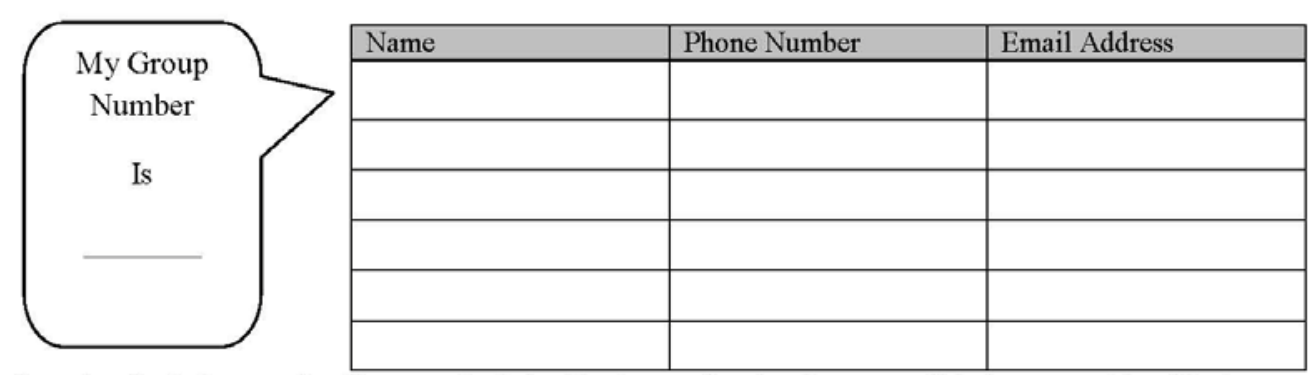

Use the calendar below to detail your schedule. Having a visual reference will help you to identify times to meet as a group.

\begin{tabular}{|c|c|c|c|c|c|c|c|}
\hline & Monday & Tuesday & Wednesday & Thursday & Friday & Saturday & Sunday \\
\hline $8: 00$ & & & & & & & \\
\hline $8: 30$ & & & & & & & \\
\hline $9: 00$ & & & & & & & \\
\hline $9: 30$ & & & & & & & \\
\hline $10: 00$ & & & & & & & \\
\hline $10: 30$ & & & & & & & \\
\hline $11: 00$ & & & & & & & \\
\hline $11: 30$ & & & & & & & \\
\hline Noon & & & & & & & \\
\hline $12: 30$ & & & & & & & \\
\hline $1: 00$ & & & & & & & \\
\hline $1: 30$ & & & & & & & \\
\hline $2: 00$ & & & & & & & \\
\hline $2: 30$ & & & & & & & \\
\hline $3: 00$ & & & & & & & \\
\hline $3: 30$ & & & & & & & \\
\hline $4: 00$ & & & & & & & \\
\hline $4: 30$ & & & & & & & \\
\hline $5: 00$ & & & & & & & \\
\hline $5: 30$ & & & & & & & \\
\hline $6: 00$ & & & & & & & \\
\hline $6: 30$ & & & & & & & \\
\hline $7: 00$ & & & & & & & \\
\hline $7: 30$ & & & & & & & \\
\hline $8: 00$ & & & & & & & \\
\hline $\begin{array}{c}8: 30 \& \\
\text { Later }\end{array}$ & & & & & & & \\
\hline
\end{tabular}




\section{How Will the Cooperative Learning Assignments Be Graded?}

The Cooperative Learning project is worth 100 points (10\%) of your final Chemistry 110 grade. Your grade on each Cooperative Learning assignment will be determined by two factors: performance on the group homework assignment and individual contribution to the group.

\section{Performance}

Your homework is due on Thursday of each week for the TuesdayThursday section and on Wednesday of each week for the Monday Wednesday-Friday sections. The group will turn in one copy with the assigned group number written in the top corner of $\mathrm{EACH}$ PAGE. Based on accuracy, each group member can earn a maximum of 10 points for each homework assignment. The group must show all of your work for each problem as well as revisions (in a different color ink). Your graded homework with feedback

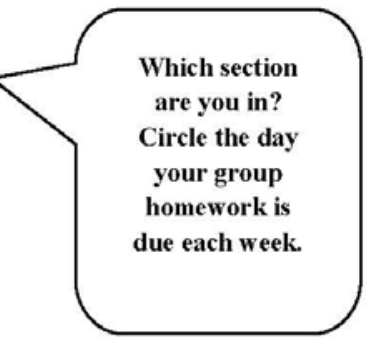
will be returned in a timely manner.

\section{Individual Contribution}

Each week you will be required to rate the individuals in your group according to their contribution to the homework assignment for that week. You will do this by completing a confidential rating scale. That is, you will assign each member a 0,1 , or a 2 based on the scale on below.

Individual Contribution Rating Scale

\begin{tabular}{|c|c|}
\hline $0=$ Did Not Participate & $\begin{array}{l}\text { - Member did not show up to the group meetings. } \\
\text { - Member attended group meetings, but did not contribute to the homework } \\
\text { assignment in any way. }\end{array}$ \\
\hline $1=$ Below Expectation & $\begin{array}{l}\text { - Member showed up but did not contribute their assigned portion(s) of the homework. } \\
\text { - Member showed up but did not fulfill assigned role. }\end{array}$ \\
\hline $2=$ At Expectation & $\begin{array}{l}\text { - Member attended group meetings. } \\
\text { - Member completed their portion(s) of the homework assignments. } \\
\text { - } \quad \text { Evember fulfilled assigned role. } \\
\text { attempted to learn and participate in the group. }\end{array}$ \\
\hline
\end{tabular}




\section{How Will the Cooperative Learning Assignments Be Graded? (continued)}

Just as you will rate your peers, they will also rate you. Based on the rating score that you receive each week, the points earned on the Cooperative Learning assignment will either stay the same or decrease. If you receive two or more ratings of a " 0 " Did Not Participate, you will receive a $0 / 10$ on your homework. If you receive two or more ratings of a "1" Below Expectation, your homework grade will be reduced by $50 \%$. Finally, if you receive two or more ratings of a "2" At Expectation, your homework grade will stay the same.

Here are three examples to help you clarify the grading procedures. Review these scenarios and ask questions if you still don't understand.

\section{Example 1:}

Your group turned in a Cooperative Learning assignment and received a perfect score 10/10.

The members in your group submitted the following rating scores for your contribution:

\begin{tabular}{|c|c|}
\hline Group member 1 gave you a 1 & \multirow{5}{*}{$\begin{array}{l}\text { You earned two ratings of } 1 \text { and three ratings } \\
\text { of } 2 \text {. Therefore, your overall score will stay a } \\
10 / 10 \text { for this Cooperative Learning } \\
\text { assignment. }\end{array}$} \\
\hline Group member 2 gave you a 2 & \\
\hline Group member 3 gave you a 1 & \\
\hline Group member 4 gave you a 2 & \\
\hline Group member 5 gave you a 2 & \\
\hline
\end{tabular}

\section{Example 2:}

Your group turned in a Cooperative Learning assignment and received a perfect score 10/10.

The members in your group submitted the following rating scores for your contribution:

\begin{tabular}{|l|l|}
\hline Group member 1 gave you a 2 & $\begin{array}{r}\text { You earned two ratings of } 2 \text { and three ratings } \\
\text { of } 1 . \text { Therefore, your overall score will be } \\
\text { reduced by } 50 \% \text { and you will receive a } 5 / 10 \text { for } \\
\text { this Cooperative Learning assignment. }\end{array}$ \\
\cline { 1 - 1 } Group member 2 gave you a 1 & \\
\hline Group member 4 gave you a 1 & gave you a 1 \\
\hline
\end{tabular}




\section{How Will the Cooperative Learning Assignments Be Graded? (continued)}

\section{Example 3:}

Your group turned in a Cooperative Learning assignment and received a perfect score 10/10.

The members in your group submitted the following rating scores for your contribution:

\begin{tabular}{|l|l|}
\hline Group member 1 gave you a 0 & $\begin{array}{c}\text { You earned two ratings of } 1 \text { and three ratings } \\
\text { of } 0 . \text { Therefore, you will receive a } 0 / 10 \text { for this } \\
\text { Cooperative Learning assignment. }\end{array}$ \\
\cline { 1 - 1 } Group member 2 gave you a 0 & \\
\cline { 1 - 1 } Group member 3 gave you a 0 & \\
\hline Group member 5 gave you a 1 & \\
\hline
\end{tabular}

\section{Example 4:}

Your group turned in a Cooperative Learning assignment and received a perfect score 10/10.

The members in your group submitted the following rating scores for your contribution:

\begin{tabular}{|c|c|}
\hline Group member 1 gave you a 1 & \multirow{5}{*}{$\begin{array}{l}\text { You earned one rating of } 0 \text {, two ratings of } 1 \\
\text { and two ratings of } 2 \text {. Therefore, you will } \\
\text { receive a } 10 / 10 \text { for this Cooperative Learning } \\
\text { assignment. Majority will always rule when } \\
\text { calculating the rating scores. Obviously, these } \\
\text { ratings scores indicate something happened } \\
\text { within the group because the members have a } \\
\text { very different perspective on the same person's } \\
\text { weekly contribution. }\end{array}$} \\
\hline Group member 2 gave you a 0 & \\
\hline Group member 3 gave you a 1 & \\
\hline Group member 4 gave you a 2 & \\
\hline Group member 5 gave you a 2 & \\
\hline
\end{tabular}




\section{How Will the Cooperative Learning Assignments Be Graded? (continued)}

It is essential that vou rate the members in vour group as fairlv and as accuratelv as possible. The rating scores will be kept confidential. Students within the groups will not have access to your rating scales at any time.

The rating scales must be emailed to your section's email address by 11:59 p.m. each Wednesday evening if you are enrolled in a Monday-Wednesday-Friday sections and by Thursday at 11:59 p.m. each Thursday for the Tuesday-Thursday section.

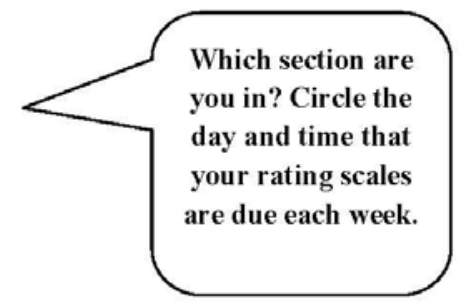

\section{Section Email Addresses}

\begin{tabular}{|c|c|l|}
\hline Check the & $\begin{array}{c}\text { If your class meets on MWF from 9:30- } \\
10: 20 \text {, send your rating scales to }\end{array}$ & chem110sec1@yahoo.com \\
\cline { 2 - 3 } box next to & $\square$ If your class meets on MWF from 10:30 \\
\cline { 2 - 3 } your & $-11: 20$, send your rating scales to & chem110sec2@yahoo.com \\
\cline { 2 - 4 } section! & $\begin{array}{c}\square \text { If your class meets on Tuesday and } \\
\text { Thursday from 10:00 - 11:15, send your } \\
\text { rating scales to }\end{array}$ & $\underline{\text { chem110sec3@yahoo.com }}$ \\
\hline
\end{tabular}


How Will the Cooperative Learning Assignments Be Graded? (continued)

Please use the following example to guide your weekly email.

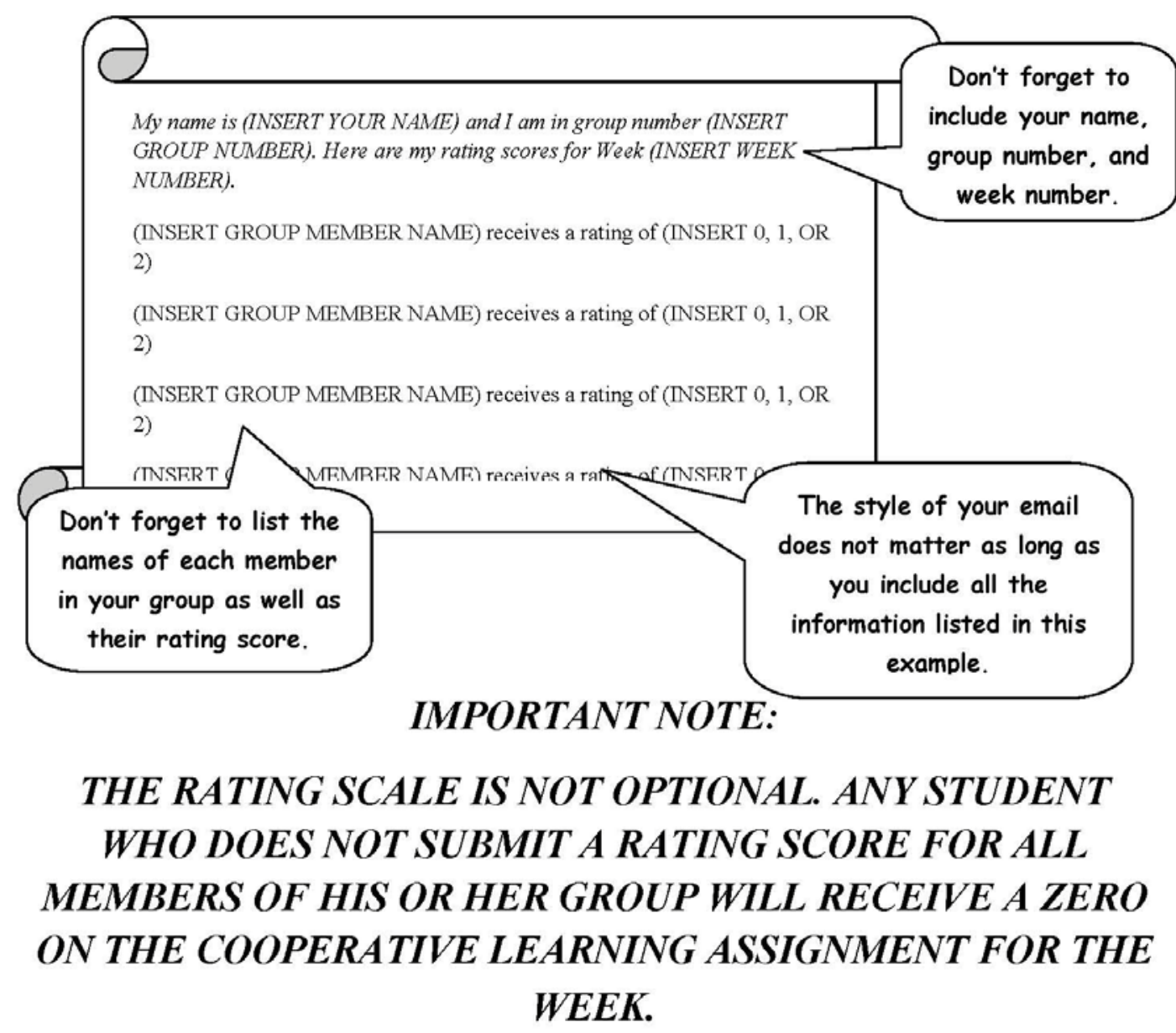

\section{Weekly Notes}

Use the Weekly Notes section to keep track of your Cooperative Learning journey. These notes will help you pinpoint where you are having difficulty as well as where you need help in terms of mastery. In addition, it will help you identify when things are going well so that you know how to keep up the good work! 


\section{Weekly Notes}

\begin{tabular}{|l|l|l|}
\hline Cooperative Learning Assignment \# 1 & Meeting Place: \\
\hline Meeting Date and Time: \\
\hline My Role this Week: \\
\hline Do I Understand the Material? How Did I Contribute to the Group this Week? \\
\hline $\begin{array}{l}\text { YES OR } \\
\text { NO }\end{array}$ & Did we accomplish our goals? \\
\hline $\begin{array}{l}\text { YES OR } \\
\text { NO }\end{array}$ & $\begin{array}{l}\text { Do all members understand the material? } \\
\text { YES OR } \\
\text { NO }\end{array}$ & $\begin{array}{l}\text { Did we maintain positive interactions } \\
\text { within the group? }\end{array}$ \\
\hline $\begin{array}{l}\text { YES OR } \\
\text { NO }\end{array}$ & $\begin{array}{l}\text { Did we solve problems in a systematic } \\
\text { manner? }\end{array}$ \\
\hline $\begin{array}{l}\text { Grade Received on Group } \\
\text { Homework: }\end{array}$ & Quiz Grade for this Week: \\
\hline
\end{tabular}

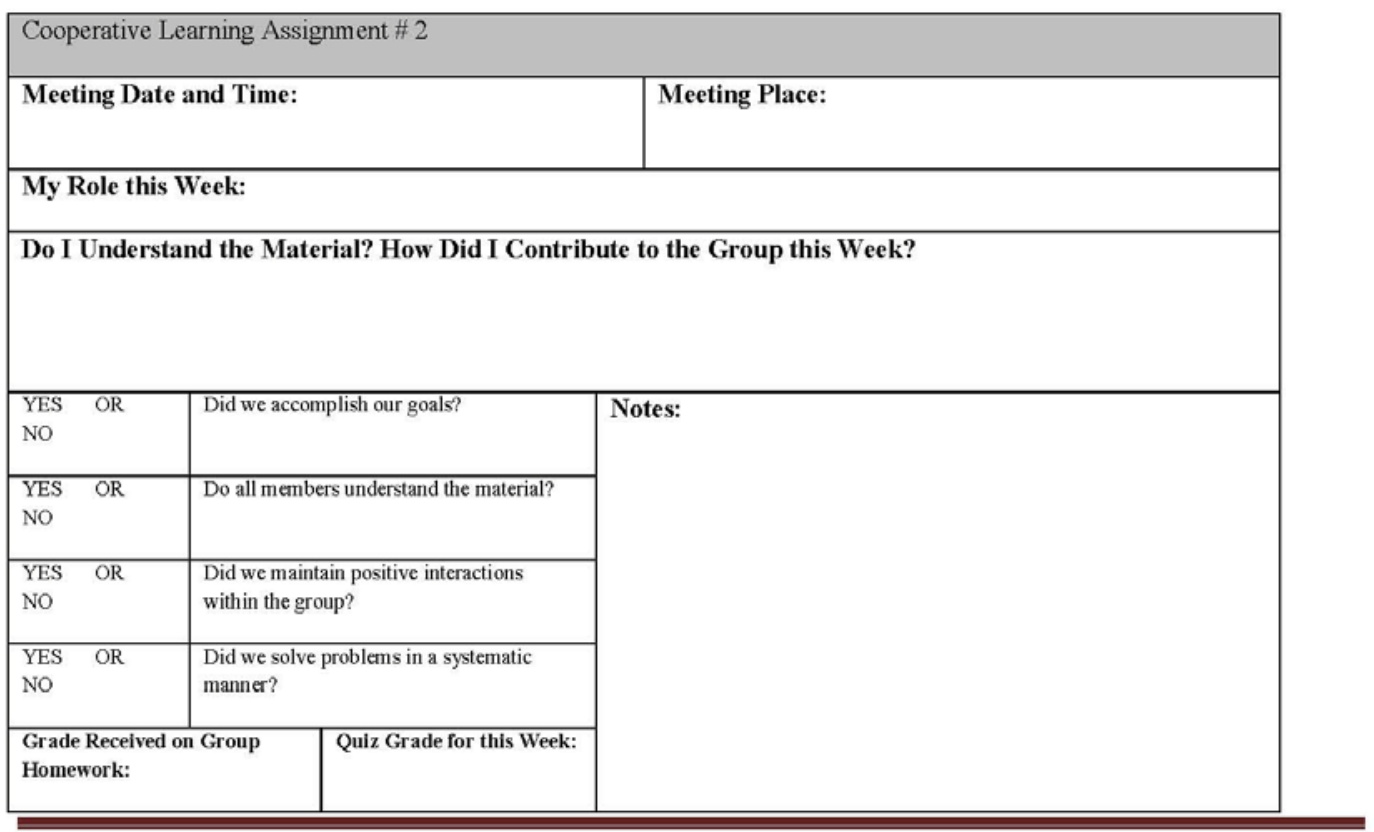

Cooperative Learning Workbook

Page 11 


\section{Weekly Notes}

\begin{tabular}{|l|l|l|}
\hline Cooperative Learning Assignment \# 3 & Meeting Place: \\
\hline Meeting Date and Time: & \\
\hline My Role this Week: \\
\hline Do I Understand the Material? How Did I Contribute to the Group this Week? \\
\hline \begin{tabular}{l|l|} 
YES OR \\
NO
\end{tabular} & Did we accomplish our goals? \\
\hline $\begin{array}{l}\text { YES OR } \\
\text { NO }\end{array}$ & Do all members understand the material? \\
\hline $\begin{array}{l}\text { YES OR } \\
\text { NO }\end{array}$ & $\begin{array}{l}\text { Did we maintain positive interactions } \\
\text { within the group? }\end{array}$ \\
\hline $\begin{array}{l}\text { YES OR } \\
\text { NO }\end{array}$ & $\begin{array}{l}\text { Did we solve problems in a systematic } \\
\text { manner? }\end{array}$ \\
\hline $\begin{array}{l}\text { Grade Received on Group } \\
\text { Homework: }\end{array}$ & Quiz Grade for this Week: \\
\hline
\end{tabular}

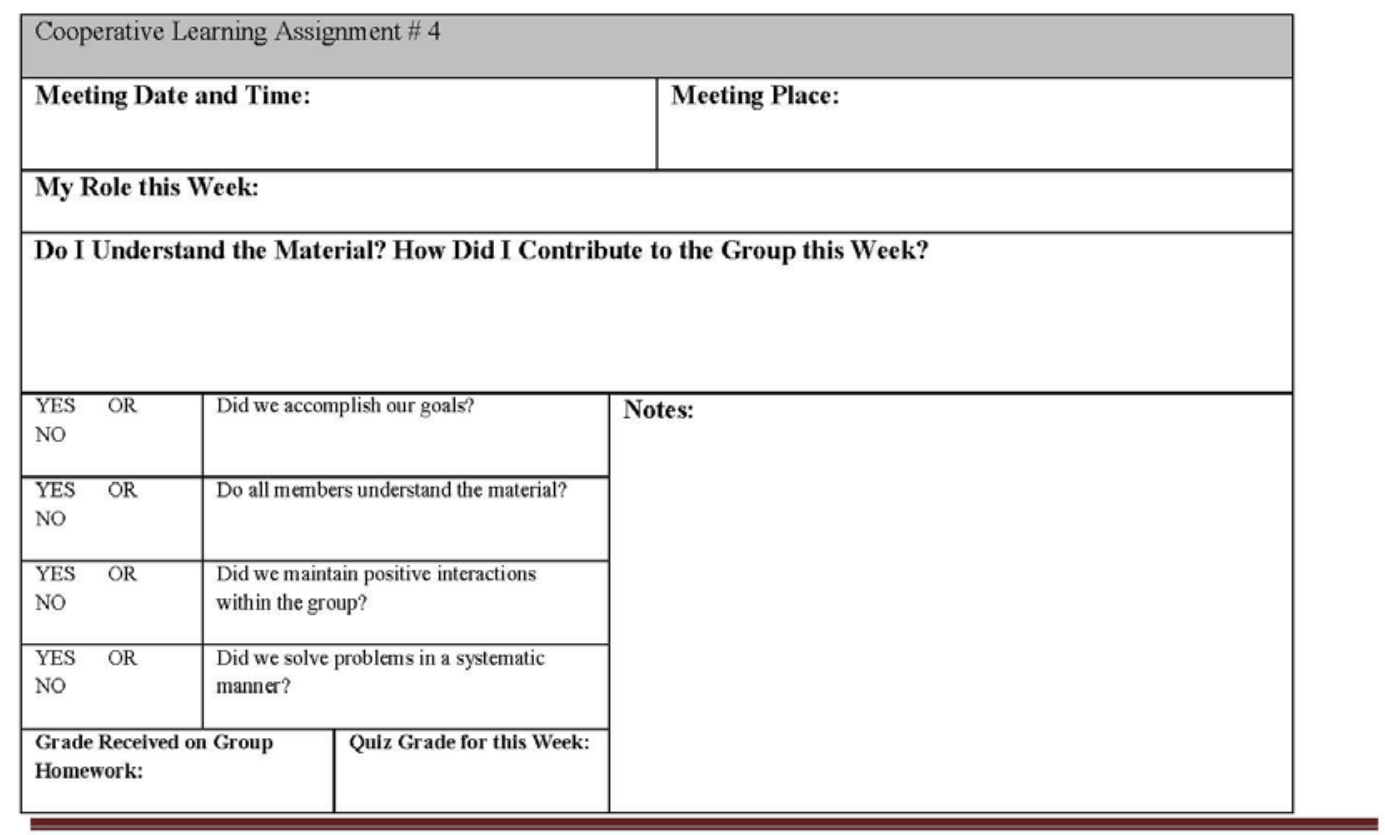

Cooperative Learning Workbook

Page 12 


\section{Weekly Notes}

\begin{tabular}{|l|l|l|}
\hline Cooperative Learning Assignment \# 5 \\
\hline Meeting Date and Time: \\
\hline My Role this Week: \\
\hline Do I Understand the Material? How Did I Contribute to the Group this Week? \\
\hline $\begin{array}{l}\text { YES OR } \\
\text { NO }\end{array}$ & Did we accomplish our goals? \\
\hline $\begin{array}{l}\text { YES OR } \\
\text { NO }\end{array}$ & $\begin{array}{l}\text { Do all members understand the material? } \\
\text { YES OR } \\
\text { NO }\end{array}$ & $\begin{array}{l}\text { Did we maintain positive interactions } \\
\text { within the group? }\end{array}$ \\
\hline $\begin{array}{l}\text { YES OR } \\
\text { NO }\end{array}$ & $\begin{array}{l}\text { Did we solve problems in a systematic } \\
\text { manner? }\end{array}$ \\
\hline $\begin{array}{l}\text { Grade Received on Group } \\
\text { Homework: }\end{array}$ & Quiz Grade for this Week: \\
\hline
\end{tabular}

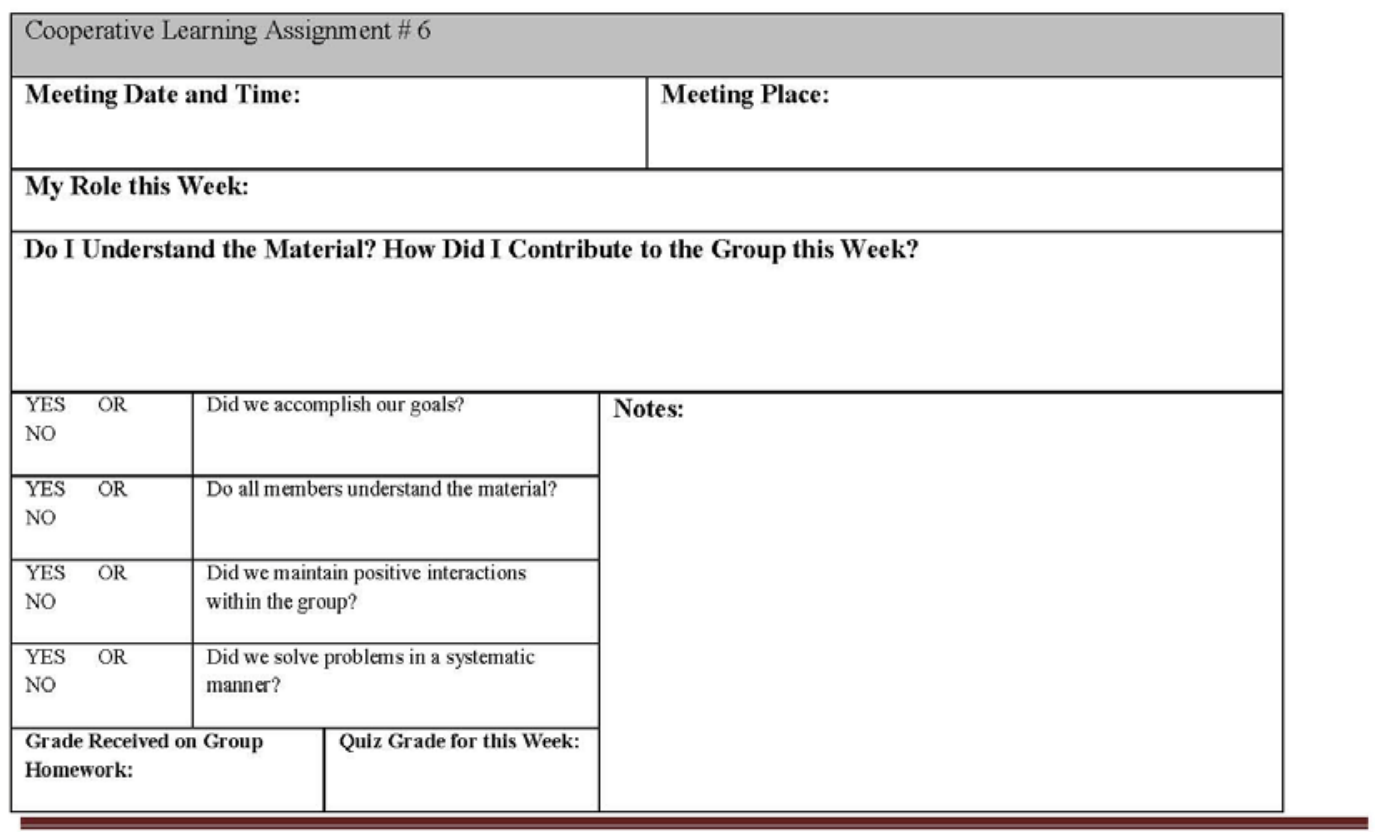

Cooperative Learning Workbook

Page 13 


\section{Weekly Notes}

\begin{tabular}{|l|l|l|}
\hline Cooperative Learning Assignment \# 7 & \multicolumn{2}{|l|}{ Meeting Place: } \\
\hline Meeting Date and Time: \\
\hline My Role this Week: \\
\hline Do I Understand the Material? How Did I Contribute to the Group this Week? \\
\hline $\begin{array}{l}\text { YES OR } \\
\text { NO }\end{array}$ & Did we accomplish our goals? \\
\hline $\begin{array}{l}\text { YES OR } \\
\text { NO }\end{array}$ & \begin{tabular}{l} 
Do all members understand the material? \\
\hline $\begin{array}{l}\text { YES OR } \\
\text { NO }\end{array}$
\end{tabular} & $\begin{array}{l}\text { Did we maintain positive interactions } \\
\text { within the group? }\end{array}$ \\
\hline $\begin{array}{l}\text { YES OR } \\
\text { NO }\end{array}$ & $\begin{array}{l}\text { Did we solve problems in a systematic } \\
\text { manner? }\end{array}$ \\
\hline $\begin{array}{l}\text { Grade Received on Group } \\
\text { Homework: }\end{array}$ & Quiz Grade for this Week: \\
\hline
\end{tabular}

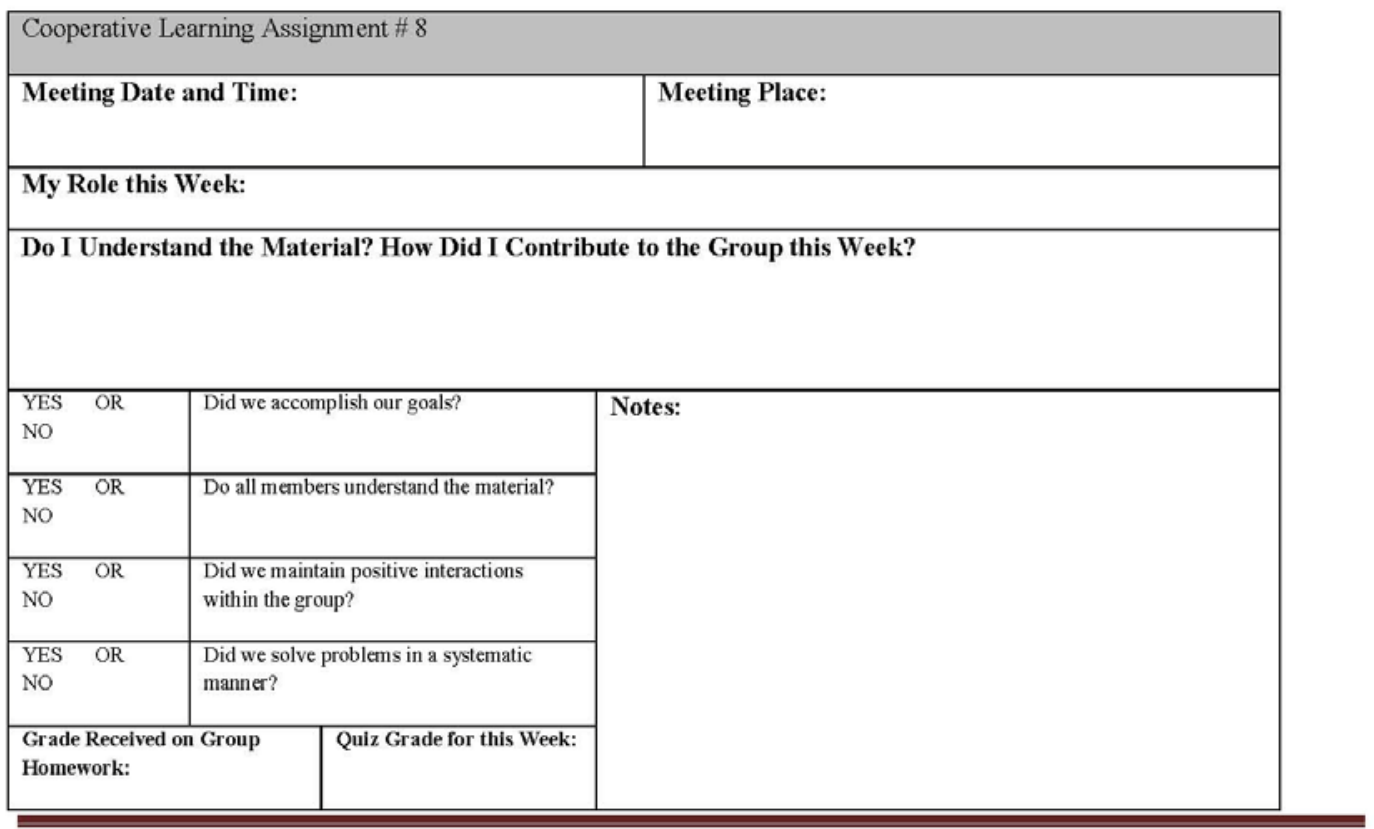

Cooperative Learning Workbook

Page 14 


\section{Weekly Notes}

\begin{tabular}{|l|l|l|}
\hline Cooperative Learning Assignment \# 9 & \multicolumn{2}{|l|}{ Meeting Place: } \\
\hline Meeting Date and Time: \\
\hline My Role this Week: \\
\hline Do I Understand the Material? How Did I Contribute to the Group this Week? \\
\hline $\begin{array}{l}\text { YES OR } \\
\text { NO }\end{array}$ & Did we accomplish our goals? \\
\hline $\begin{array}{l}\text { YES OR } \\
\text { NO }\end{array}$ & $\begin{array}{l}\text { Do all members understand the material? } \\
\text { YES OR } \\
\text { NO }\end{array}$ & $\begin{array}{l}\text { Did we maintain positive interactions } \\
\text { within the group? }\end{array}$ \\
\hline $\begin{array}{l}\text { YES OR } \\
\text { NO }\end{array}$ & $\begin{array}{l}\text { Did we solve problems in a systematic } \\
\text { manner? }\end{array}$ \\
\hline $\begin{array}{l}\text { Grade Received on Group } \\
\text { Homework: }\end{array}$ & Quiz Grade for this Week: \\
\hline
\end{tabular}

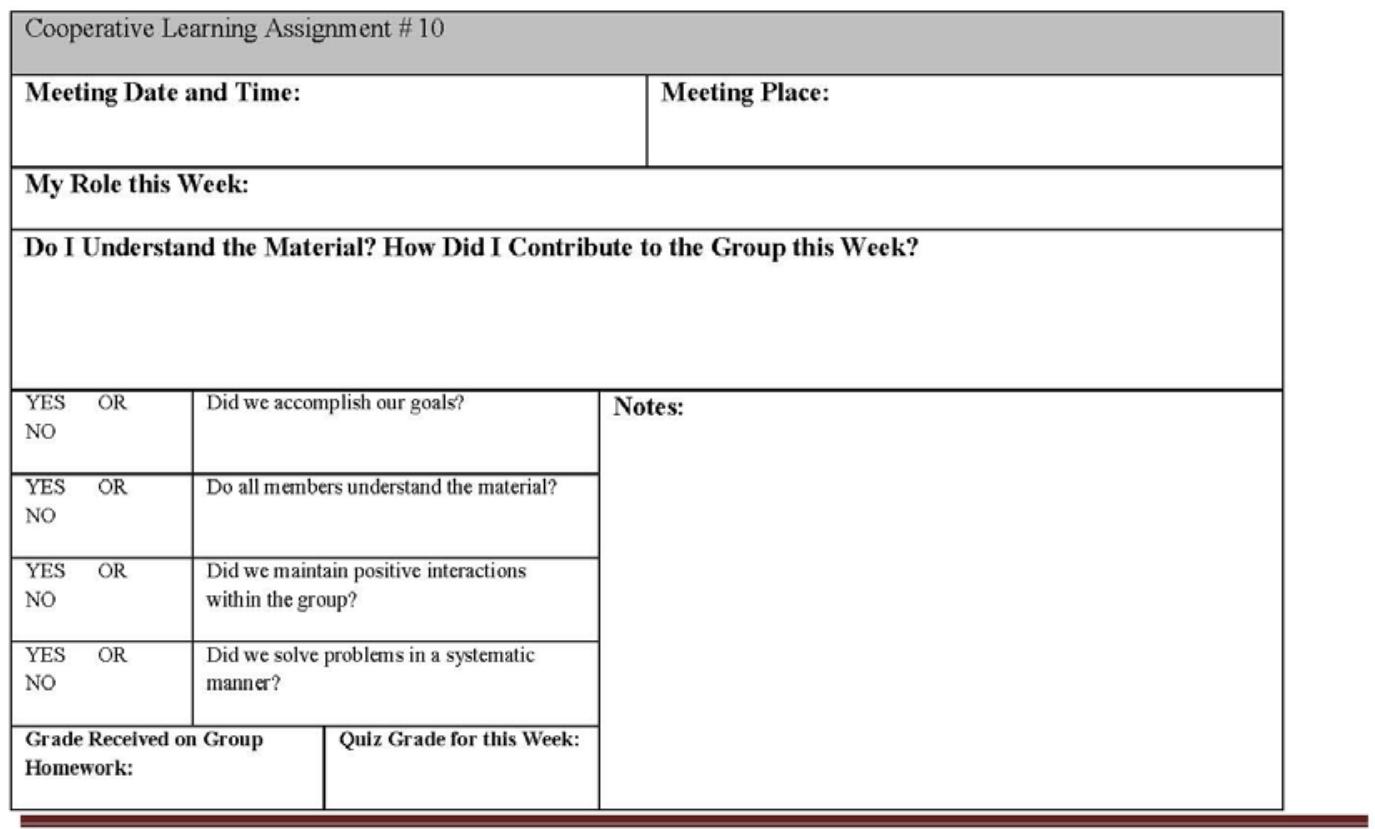

Cooperative Learning Workbook

Page 15 


\section{Social Skills Information Sheet}

Just as Cooperative Learning is linked to increased performance, it is also associated with better use of social skills. Given the world we live in and the fact that most work and educational settings involve other people, it is important to practice social skills that help us work together in meaningful ways.

\begin{tabular}{|c|c|c|}
\hline \multirow{4}{*}{ 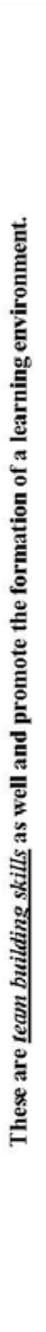 } & Communication & $\begin{array}{l}\text { - Speak clearly. } \\
\text { - Use good voice quality and maintain correct pace when speaking. } \\
\text { - Urite legibly. } \\
\text { - } \quad \text { Maintain listening skills. } \\
\text { - }\end{array}$ \\
\hline & $\begin{array}{l}\text { Active Listening } \\
\text { Skills }\end{array}$ & $\begin{array}{l}\text { - Set a purpose for listening. Ask yourself what you want to achieve. } \\
\text { - } \quad \text { Keep a jot list to record items that cause your thoughts wander. } \\
\text { - Think of questions as you are listening. } \\
\text { - Don't jump to conclusions. } \\
\text { - Don't stop listening because of a distraction. } \\
\text { - } \quad \text { Be prep't give up because the subject is difficult. } \\
\text { - Complete any necessary pre-work. } \\
\text { - Don't interrupt others while they are speaking. }\end{array}$ \\
\hline & Leadership & $\begin{array}{l}\text { - } \quad \text { Be on time and prepare. } \\
\text { - } \text { Complete your portion of the work on time. } \\
\text { - } \quad \text { Keep the group on track. } \\
\text { - Set a positive example. } \\
\text { Acknowledge when there is a problem that the group can not solve and } \\
\text { seek outside help. }\end{array}$ \\
\hline & Decision-Making & $\begin{array}{l}\text { You must recognize and respect all opinions, ideas, suggestions, and perspectives. } \\
\text { You may not reach a unanimous decision as a group, but everyone must come to } \\
\text { agreement or consensus. This means you may have to accept a different point of } \\
\text { view for the betterment of the group. } \\
\text { - Avoid arguing and present positions logically. } \\
\text { - Avoid "win-lose" statements. Discard the notion that someone must win. } \\
\text { - Avoid changing of minds only in order to avoid conflict and to achieve } \\
\text { - Avoid majority voting, averaging, bargaining, or coin flipping. These do } \\
\text { not lead to consensus. Treat differences of opinion as indicative of } \\
\text { incomplete sharing of relevant information, keep asking questions. } \\
\text { - Keep the attitude that holding different views is both natural and healthy to } \\
\text { a group. }\end{array}$ \\
\hline
\end{tabular}




\section{Social Skills Information Sheet (continued)}

\begin{tabular}{|l|l|l|}
\hline Management & $\begin{array}{l}\text { Conflict of some type is inevitable and to some degree can be healthy. Recognize it } \\
\text { early and work to resolve the issues. Destructive conflict interferes with the } \\
\text { group's ability to reach their common goal of content mastery. It is usually the } \\
\text { result of poor communication, lack of trust in the group, and weak group } \\
\text { management - another reason it is essential to assign and rotate roles each week. } \\
\text { However, it can be a good thing when it is used to clarify problems and generate } \\
\text { solutions. It can facilitate good communication and actually help with content } \\
\text { mastery as team members explain and actively listen to one another. }\end{array}$ \\
& $\begin{array}{l}\text { Discuss issues and be honest. } \\
\text { - Set goals for the group. }\end{array}$ \\
& Agree to disagree when necessary.
\end{tabular}

Portions of the Social Skills Information Sheet were taken from the following websites:

http://www.nsba.org/sbot/toolkit/Conflict.html

http://www.elmhurst.edu/library/learningcenter/Listening/suggestions for active listening.htm 